\title{
GROWING AN EDIBLE CAMPUS
}

by

\section{Sean O'Brien Murray}

Bachelor of Arts, Cape Breton University, Sydney, Nova Scotia, 2015

A thesis presented to Ryerson University joint with York University

in partial fulfilment of the requirements of the degree of

Master of Arts

in the program of

Communication and Culture

The views expressed by the research participants reflect personal opinion not the opinion of their respective post-secondary institutions.

Toronto, Ontario, Canada, 2018

(C) Sean O'Brien Murray, 2018 


\section{Author's Declaration}

I hereby declare that I am the sole author of this thesis. This is a true copy of the thesis, including any required final revisions, as accepted by my examiners.

I authorize Ryerson University to lend this thesis to other institutions or individuals for the purpose of scholarly research.

I further authorize Ryerson University to reproduce this thesis by photocopying or by other means, in total or in part, at the request of other institutions or individuals for the purpose of scholarly research.

I understand that my thesis may be made electronically available to the public. 
Growing An Edible Campus

Sean O’Brien Murray

Communication and Culture, Ryerson University, 2018

\begin{abstract}
An Edible Campus can be broadly defined as the production of food on a post-secondary institution's campus. This research contributes to the creation of a Canadian Edible Campus Database (ECD) that can be used as a network for future collaborations within the campus sustainability community, thus creating opportunities for education, research and community engagement. The database contains information about practices, size, and origin of Edible Campuses across Canada. The database also creates a participant pool for a survey aimed at understanding the diversity of Edible Campuses. Edible Campus team members were asked to respond to questions regarding the goals, barriers and benefits for their food production initiatives. It is the finding of this research that Edible Campuses often exceed beyond 'greening the school' by demonstrating sustainability through the physical structure, teaching practice, research, and relationships with people and nature.
\end{abstract}




\section{Acknowledgements}

I would first like to thank my thesis advisor Dr. Stéphanie Walsh Matthews of the Arts and Contemporary Studies program at Ryerson University. Dr. Matthews helped guide the direction of this work while allowing the research to be my own.

I would also like to acknowledge Dr. David Ciavatta from the department of Philosophy at Ryerson University and Dr. Andrew Millward from the department of Geography and Environmental Studies at Ryerson University. I am grateful for the time they took to review and provide insightful comments which ultimately helped to strengthen this research.

Finally, I would like to thank the people who took the time to thoughtfully complete the Edible Campus survey. 


\section{Dedication}

This work is dedicated to my dad who helped me create my first garden and took me on countless adventure walks through our farm. 


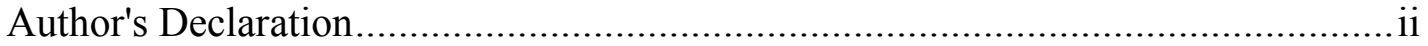

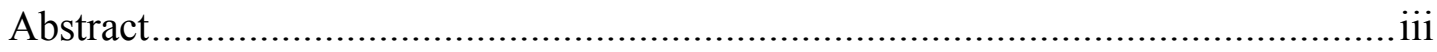

Acknowledgements ......................................................................................... iv

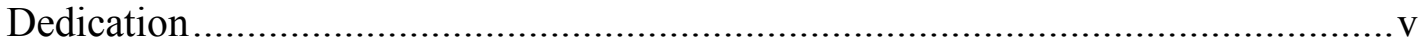

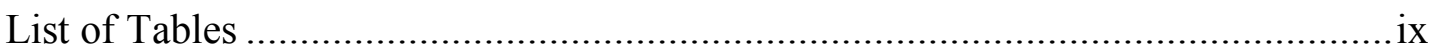

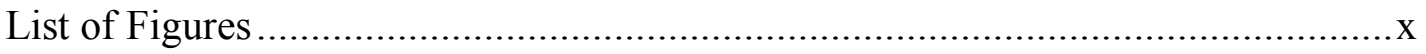

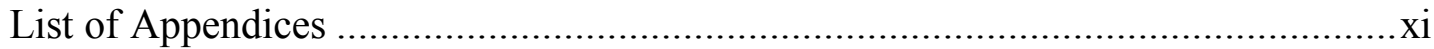

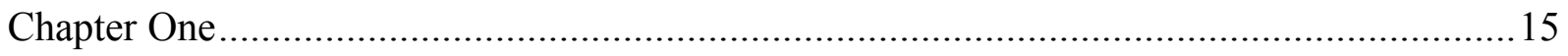

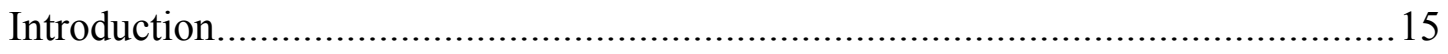

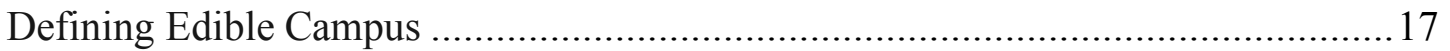

Section: History and Rationale of the Term Edible Campus........................................17

Defining Campus Sustainability ……………………….................................... 19

History of Food Production in Higher Education .......................................................22

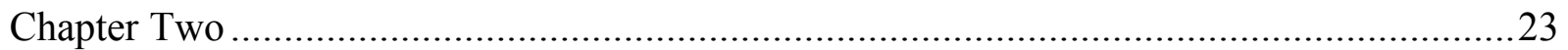

Review of Literature

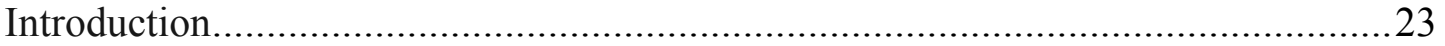

History and Rationale of the Term Edible Campus ..................................................24

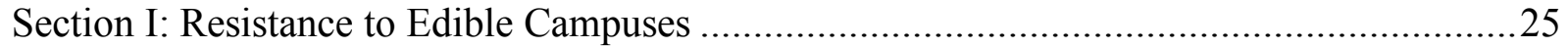

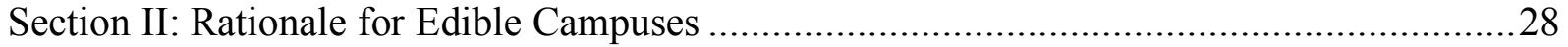

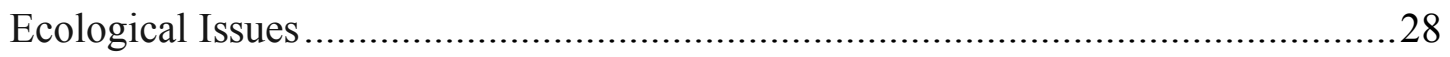

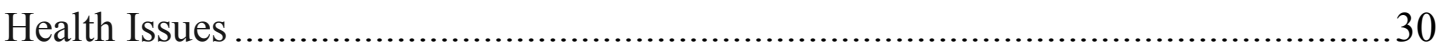

Alternative Food Systems.................................................................................... 32

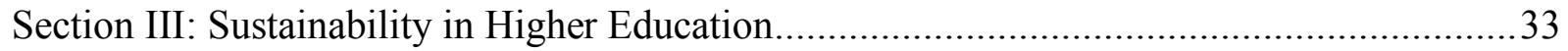

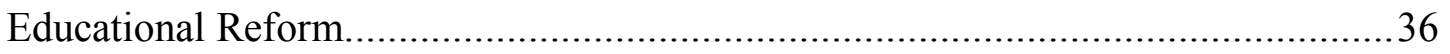

Section IV: Gaps in Evaluation Frameworks and Guidelines ................................................... 37

Evaluating Sustainability and Well-being in Education..............................................38

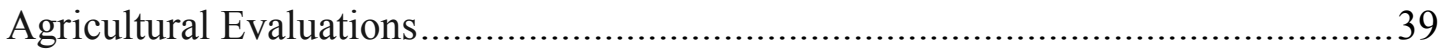

Guides for Student-run Food Production..............................................................40

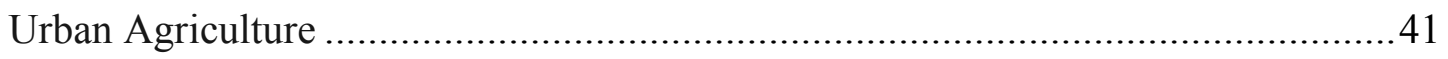




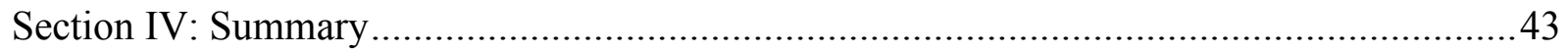

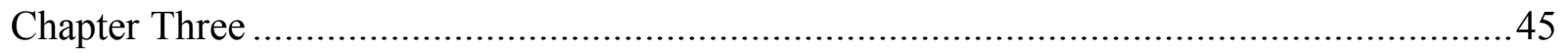

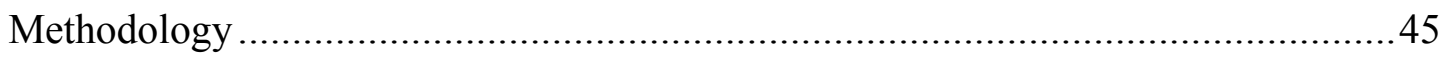

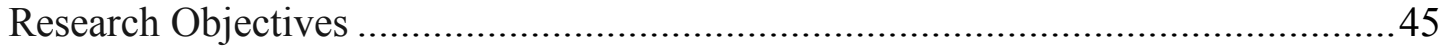

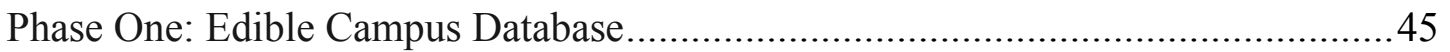

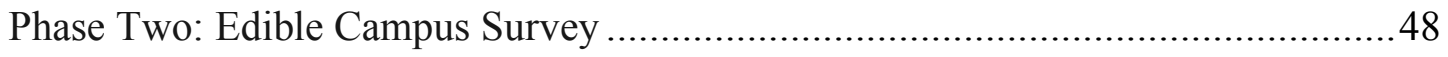

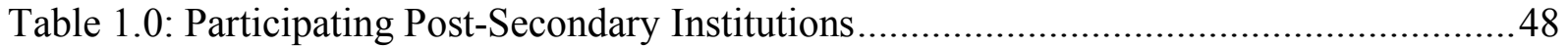

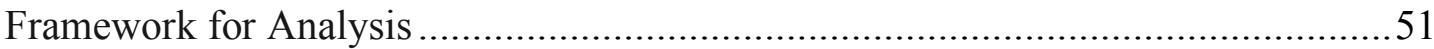

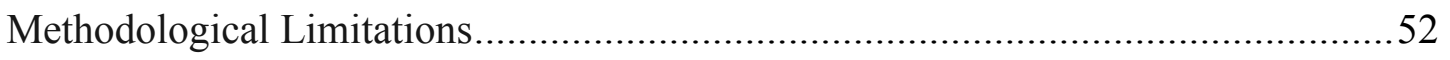

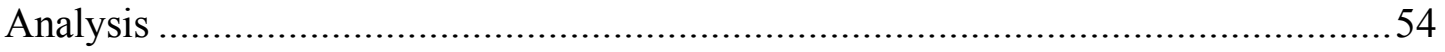

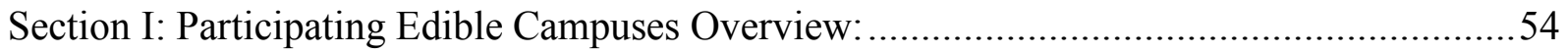

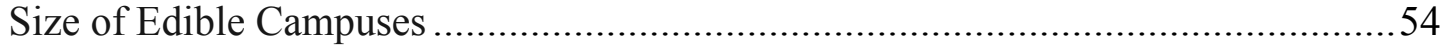

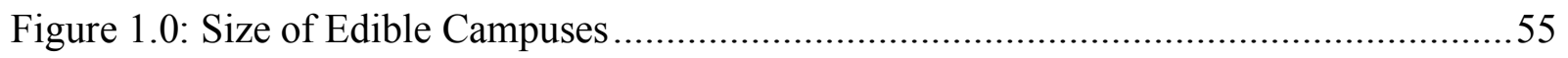

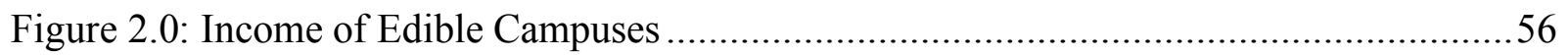

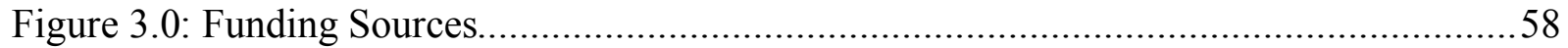

Spaces Edible Campuses Occupy ……………………………………………....5

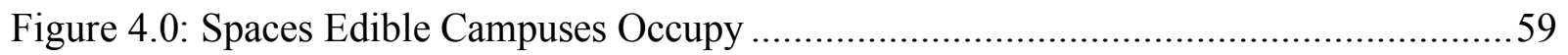

Figure 5.0: Past Uses for Edible Campus Spaces ....................................................................6

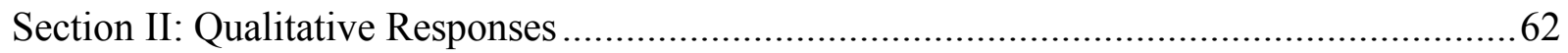

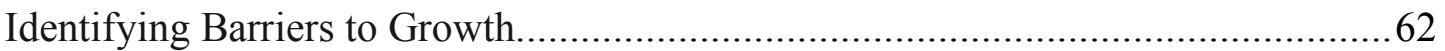

Benefits of an Edible Campus.................................................................................64

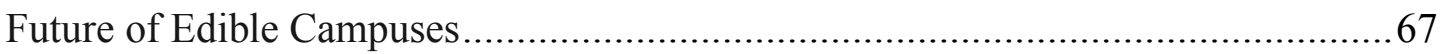

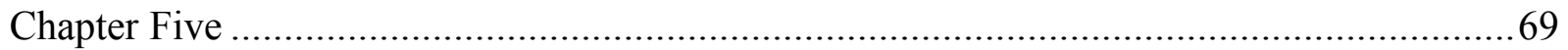

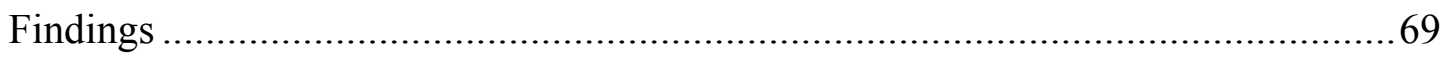

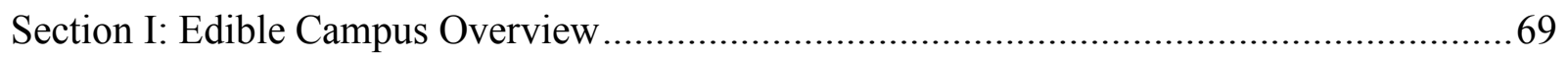

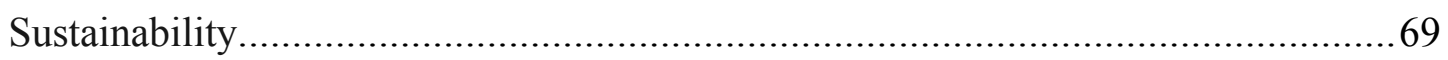

Size to Income Earning Potential.......................................................................

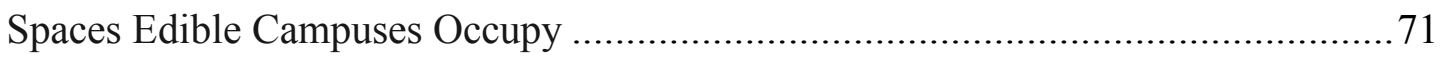

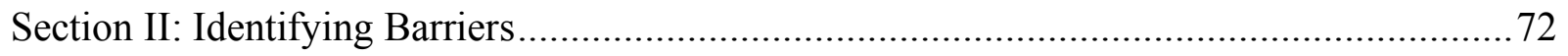

Funding and Commitment from Post-Secondary Institution....................................72 


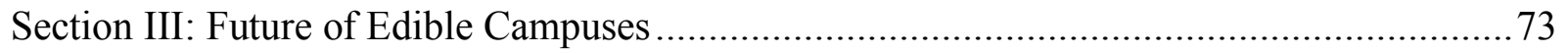

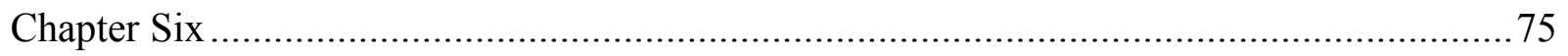

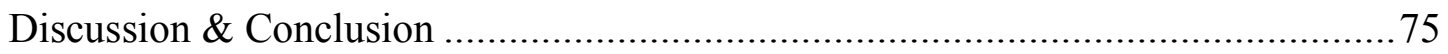

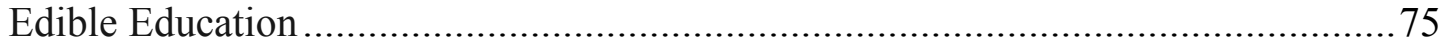

Benefits and Downfalls of Small Localized Projects.................................................76

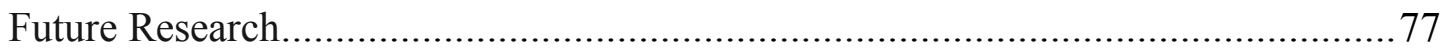

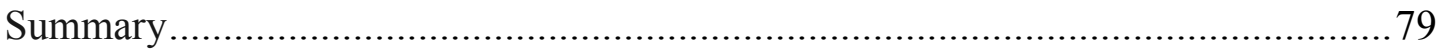

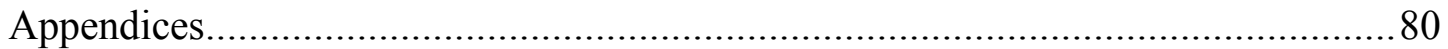

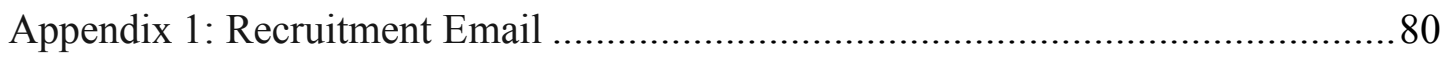

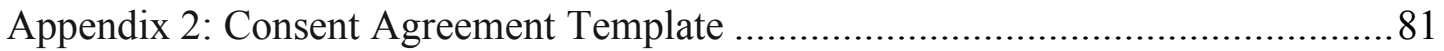

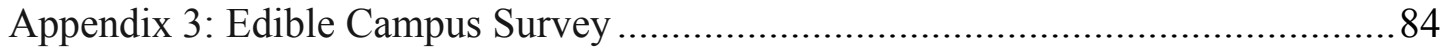

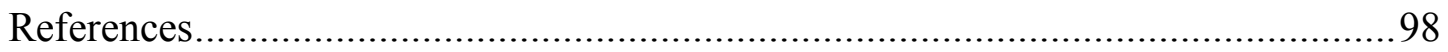




\section{List of Tables}

Table 1.0: Participating Post-Secondary Institutions .................................................... 48 


\section{List of Figures}

Figure 1.0: Size of Edible Campuses ........................................................................ 55

Figure 2.0: Income of Edible Campuses ............................................................... 56

Figure 3.0: Funding Sources................................................................................ 58

Figure 4.0: Spaces Edible Campuses Occupy ........................................................... 59

Figure 5.0: Past Uses for Edible Campus Spaces ................................................... 60 


\section{List of Appendices}

Appendix 1: Recruitment Email ........................................ 79

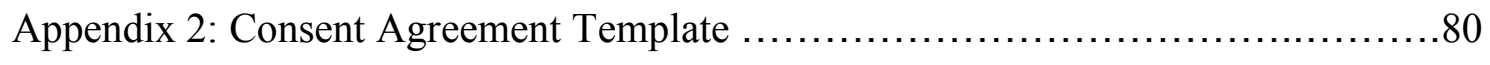

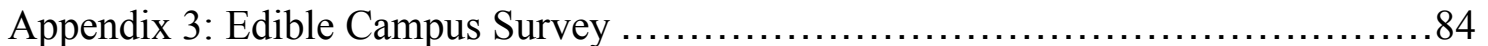


... but the act I want to talk about is growing some — even just a little — of your own food. Rip out your lawn, if you have one, and if you don't — if you live in a high-rise, or have a yard shrouded in shade — look into getting a plot in a community garden. Measured against the Problem We Face, planting a garden sounds pretty benign, I know, but in fact it's one of the most powerful things an individual can do - to reduce your carbon footprint, sure, but more important, to reduce your sense of dependence and dividedness: to change the cheap-energy mind.

Michael Pollan (New York Magazine, 2008a, para 20) 


\section{Chapter One}

\section{Introduction}

The capacity of institutions of higher education to pioneer alternative sustainable food systems that embody ethical principles has moved beyond the stage of a few pilot projects. This research proposes the term 'Edible Campus' to describe food production that is intertwined with a postsecondary campus to create accessible, local, and economical food sources. Despite the growing interest in campus sustainability, scholarly literature rarely presents Edible Campuses as the focal point of such discussion or research. This study addresses a gap in the literature by identifying potential benefits of Edible Campuses as contributors to campus sustainability through a survey of Canadian Edible Campuses. Secondly, this research creates a Canadian Edible Campus Database (ECD) that can be used as a network for future collaborations within the campus sustainability community, thus creating future opportunities for education, research, and community engagement oriented towards sustainable food production.

Canadian Edible Campus case studies were chosen as the scope of this research, in part, because a global perspective exceeds the limitations of a Masters thesis. Additionally, it was enticing to add a Canadian perspective to the predominantly American literature I was reading during the early months of this research. Perhaps most importantly, Canada offers a diverse landscape for cultivating food. Essentially, a sampling of the best practices of Canadian post-secondary institutions could be applied or used as a source of inspiration for many areas around the world. The extreme and often unpredictable weather conditions that hit the East Coast of Canada create 
a unique set of obstacles compared to those faced by growers in a metropolitan area like Toronto. While East Coast growers are battening down the hatches as a winter storm rolls in, Toronto growers have to be space conscious, often thinking upward as opposed to outward.

This research theorized that even campus specific learning processes could be adapted or directly applied from one Edible Campus to another Edible Campus. For example, a space conscious urban farmer may opt to grow indoors and the learning process, if shared, could aid a rural grower who hopes to bring food production into a classroom. Similarly, an Edible Campus team may create an evaluation framework that could inspire positive change within another Edible Campus. A preliminary investigation found that at the present time Canadian Edible Campus teams rarely collaborate or share learning processes with one another. Hence, an ECD creates the opportunity for increased awareness of projects within the campus sustainability community and collaboration amongst post-secondary institutions.

While building the Edible Campus database, I found that post-secondary institutions frequently cultivate multiple food projects on one campus under various titles. One of the appeals of using the term Edible Campus is that it is inclusive of the diversity of food production projects found on one campus. Additionally, the term Edible Campus can be used globally without requiring a unified image of what shape the campus food production takes. For example, Edible Campuses 
can take the form of rooftop gardens, classroom gardens, guerrilla gardening ${ }^{1}$ and large scale farms to name a few. Whereas a term such as Urban Farm (Ryerson University) creates a preconceived notion as to the location and size of the project, perhaps most importantly, utilizing the term Edible Campus changes the narrative regarding how we think about food production by intertwining it with education.

As there is limited scholarship on Canadian campus-based food production, a survey [Appendix 3] was developed to better understand the diversity of sizes, goals and management styles of Canadian Edible Campuses. Members of Edible Campus teams described the barriers they identified for post-secondary food production as well as what they envisioned the future of Edible Campuses to be.

\section{Defining Edible Campus}

To date the term Edible Campus has been utilized by several post-secondary institutions (e.g. McGill) to describe food production projects referring to their specific campus. However, it has not previously been defined for the purposes of academic research. See: Literature Review, Section: History and Rationale of the Term Edible Campus for further discussion.

${ }^{1}$ Guerrilla Gardening describes gardening without permission in unowned or public spaces. Guerrilla gardening can be a form of activism as well as an example of a local, self-determined, critical and expressive act. (Reynolds, 2009) 
For the purpose of this research, "Edible Campus" is defined as food production on the campus of post-secondary institutions. Food production on post-secondary campuses is frequently cultivated in under-utilized spaces such as rooftops. However, food production can also take place in a multitude of locations such as classrooms, greenhouses and converted lawn space. Multiple food production projects on one campus are captured within the term Edible Campus.

Other terms actively associated with Edible Campuses are campus-based food production, sustainable schools, community gardens, civic agriculture ${ }^{2}$ and living schools ${ }^{3}$. These terms may also be used to describe an Edible Campus depending on the form it takes. For example, not all living schools cultivate food.

In this study, the term Edible Campus is not inclusive of medicinal plant life that is inedible or livestock. There are a number of reasons these exclusions foremost, livestock is often kept on rural campuses thus inclusion within this research would skew research participate recruitment. Secondly, a study of medicinal plant life on campuses redirects the research questions this thesis

${ }^{2}$ Civic agriculture "embraces innovative ways to produce, process, and distribute food, and it represents a sustainable alternative to the socially, economically, and environmentally destructive practices associated with industrial large-scale agriculture. Farmers' markets, community gardens, and community-supported agriculture are all forms of civic agriculture.” (Lyson, 2012, p.1)

${ }^{3}$ Living schools are on the leading edge of transforming education through the integration of sustainability and new pedagogies (O’Brien \& Howard, 2016). A living school reflects an education vision of wellbeing for all (Hopkins, 2013), incorporates new pedagogies (Fullan, 2013; Fullan \& Langworthy, 2014) and sustainability education. 
asks. While this research focuses on plant life, the term Edible Campus could be expanded to include campus beekeeping as it gains popularity and as beehive designs continue to develop to accommodate to urban environments. Please see the future research section for more detail on expanding the term Edible Campus.

\section{Defining Campus Sustainability}

Discussing campus sustainability can be an ambiguous prospect considering the broad range of definitions that post-secondary institutions are using for sustainability, as mentioned above. A contributing factor to these diverse views is that it is easy for individuals to make assumptions about the meaning of the term based on their experiences with campus sustainability. To some, the term may invoke skepticism if it is understood to be synonymous with disingenuous attempts to green a school's image as opposed to implementing impactful environmentally sustainable changes. Others may see it as the latest 'buzzword' that will eventually be replaced by something else. Thomashow (2014) describes these ideological challenges in Nine Elements of a Sustainable Campus. (See Literature Review Section: Opposition to Edible Campus for further discussion). Although there is skepticism towards campus sustainability, this research finds that through an extensive literature review and survey results find that Edible Campuses have benefits that support further research.

Campus sustainability has been understood as both an ethos and a goal to be achieved that can be realized through an institution's values, strategic plans, policies and practices (Thomashow, 2014, p.15). Most campuses abide by this and have for many years. In practice, campus sustainability frequently takes the form of enacting sustainable waste management systems, 
converting to renewable power sources or proposing a policy that places importance on ecological issues. While the concept of sustainability is widely understood to include economic, environmental and social sustainability, a notable absence in the campus sustainability assessment literature is the incorporation of social sustainability (Brinkhurst, Rose, Maurice, \& Ackerman, 2011). Practical environmental sustainability indicators such as energy use, waste management, recycling, and water usage appear to hold a privileged or elevated position presumably because of the large-scale effect such management and acts have on society and its partners. Additionally, while many post-secondary institutions have increased their focus on student well-being, primarily in response to rising concerns about student mental health, student well-being does not tend to be integrated with campus sustainability strategies and reports (Canadian Association of College \& University Student Services and Canadian Mental Health Association, 2013; MacKean, 2011). For example, social sustainability is not mentioned in any of the measures taken by the top eight schools in the College Sustainability Report Card 2011 (Finlay \& Massey, 2012).

For this research, I focus on campus sustainability through the scope of food production: an approach to living and learning that links food production and consumption to ecological awareness. Campus sustainability intertwines food, environmental sustainability, and education to draw attention to how facets of everyday life affect individuals, communities, the natural world and future generations. As such, it can be seen to include social sustainability.

The 'benefits' of an Edible Campus to students, staff and community can be explored in part through existing scholarship on community gardens and campus green projects. From this 


\section{Growing An Edible Campus}

perspective, the benefits of an Edible Campus in terms of food security and campus culture have been explored at length. This research will not conduct a rigorous overview (or comprehensive review) of the aforementioned topics and will instead explore the rationale for an Edible Campus in relation to educational reform, campus sustainability, health, and alternative food systems. Edible Campuses as a form of educational reform and alternative food system are emerging areas of academic discussion. Furthermore, Edible Campuses within the larger campus sustainability movement is increasingly a point of interest within academic writing, social media, blogs and news outlets. A discussion on the health benefits of Edible Campuses will be situated within the rationale for Edible Campuses as presented by post-secondary institutions. Along with ecological action, the health of students and staff is primarily cited by post-secondary institutions as the rationale for maintaining food production on campus. ${ }^{4}$

\footnotetext{
${ }^{4}$ For further reading on how Edible Campuses can improve the mental/physical health for post-secondary staff, students and faculty please see: Armstrong (2000); Patterson \& Kline (2008); Van Den Berg \& Custers (2010). In terms of Edible Campuses benefiting food insecure individuals please see: Black (2014); Chaparro, Zaghloul, Holck \& Dobbs (2009). Regarding opportunities for sustainable food education and employment see: Finlay \& Massey (2012); Draper \& Freedman (2010). Draper \& Freedman (2010) have also written on how campus green projects contribute to the revitalization of unused space, beautification and opportunities for cultural preservation, expression and community empowerment. Finally, Woodcraft (2012) wrote on how Edible Campuses can foster a sense of community that "transcends disciplines" (p.45).
} 
History of Food Production in Higher Education

Food production research conducted by institutions of higher education in Canada has existed for generations (Lawson, 2005; Montanari, Sonnenfeld, Flandrin, 1999; Sayre, 2011). For example, the University of Guelph's Ontario Agricultural College cultivated crops for experimental research since 1878, and the Glenlea Research Station owned by the University of Manitoba has studied field crops since 1966 ("Our History | Plant Agriculture", 2017; "University of Manitoba - Glenlea Research Station", 2017). However, it is only since the 1990's that an influx of campus-based food production began sprouting up, described by Creighton (1998) as the "greening of the ivory tower".

As post-secondary institutions were affected by the financial crisis of 2008, so were their Edible Campuses. As such, many suspended or reduced funding to campus gardens. Consequently, the prominence of Edible Campuses suffered as, at the time, few were self-sustaining (Ridgeway \& Matthews, 2015 citing Bell, 2013).

Nearly a decade later, many Edible Campuses are a vital part of campus culture (especially those with agricultural programs and/or Geography programs) and as this research will demonstrate $61.9 \%$ are pivotal to food research. The University of Guelph, a participant in this research, now operates 11 off-site research farms, totalling several hundred hectares, while the University of Manitoba's Glenlea Research Station alone consists of approximately 400 hectares (Maclean's, 2011). These operations dwarf many of the Edible Campuses included within the database created by this research. 


\section{Chapter Two}

\section{Review of Literature}

\section{Introduction}

Edible Campuses build upon the pioneering work of farmers, advocacy groups, chefs and leaders in education who have critiqued the conventional agricultural food system and called for impactful environmental action (Allen, 2010; Pollan, 2006; Price \& Gottlieb, 2002; Thomashow, 2014; University Leaders for a Sustainable Future, 2001; Waters, 2009). However, despite a growing interest and support for campus sustainability and sustainable food production, Edible Campuses are rarely presented as the focal point of scholarly research. Therefore, this literature review will largely examine Edible Campuses in relation to alternative food systems, campus sustainability, health and well-being, and sustainable food production.

This review will also examine how Edible Campuses meet a need for educational reformoriented towards sustainability that has been identified and recommended by leaders in education (Aber, Kelly \& Mallory, 2009; Fullan \& Langworthy, 2014; Hopkins, 2013; Vickery, 2017) and how Edible Campuses fit within proposed frameworks for addressing ecological concerns within global policy (ISCN in Collaboration with GULF of The World Economic Forum, 2017).

Furthermore, there is no comprehensive framework for evaluating Edible Campuses in terms of the benefits to the students, staff, post-secondary institution, surrounding community and the environment. Therefore, this literature review will examine evaluations for agriculture and 
campus sustainability. The history and rationale behind the term 'Edible Campus' lays the foundation for this discussion.

\section{History and Rationale of the Term Edible Campus}

While post-secondary institutions frequently utilize terms that are specific to describing food production projects on their campuses, there is not yet an umbrella term for describing the diversity of campus food production initiatives. For example, the Centre for Sustainable Food Systems is used by the University of British Columbia. To my knowledge, the term Edible Campus is used only by McGill University, the University of California, the University of Utah and the University of Victoria. However, these four institutions use the term Edible Campus to describe food production on their reflective campuses not more broadly as it is used in this research.

While building the Edible Campus database, I found that post-secondary institutions frequently cultivate multiple food projects on one campus under various titles. One of the appeals of using the term Edible Campus is that it is inclusive of the diversity of food production projects found on one campus. Additionally, the term Edible Campus can be used globally without requiring a unified image of what shape the campus food production takes. For example, Edible Campuses can take the form of rooftop gardens, classroom gardens, guerrilla gardening ${ }^{5}$ and large-scale

\footnotetext{
${ }^{5}$ Guerrilla Gardening describes gardening without permission in unowned or public spaces.
} Guerrilla gardening can be a form of activism as well as an example of a local, self-determined, critical and expressive act. (Reynolds, 2009) 
farms to name a few. Whereas a term such as Urban Farm (Ryerson University) creates a preconceived notion as to the location and size of the project, perhaps most importantly, utilizing the term Edible Campus changes the narrative regarding how we think about food production by intertwining it with education.

\section{Section I: Resistance to Edible Campuses}

This section will briefly provide an overview of the opposition to Edible Campuses with the understanding that no single intervention has the capacity to be a complete solution to the complex problem of restoring equilibrium to unsustainable industrial food systems. Similarly, a culture of sustainability within higher education can only be achieved through a diversity of interventions.

Opposition to Edible Campuses is largely comprised of skepticism regarding the economic realities of campus food production (Bhatt, Farah, Luka \& Wolfe, 2009) and the legitimacy of its social and environmental impact (Friedmann, 1993). Scholars and food activists alike doubt that the development of alternative food systems such as Edible Campuses are capable of adequately addressing the systemic issues arising from the industrial food system (Dupuis, Goodman \& Harrison, 2006). Similarly, critics doubt the political impact and transformational capacity of campus projects (Ridgeway \& Matthews, 2015; Wright \& Middendorf, 2008).

Dr. Mitchel Thomashow, President of Unity College (Maine, USA), described the pushback from colleagues during the proposal phase of implementing campus sustainability initiatives in 
The Nine Elements of a Sustainable Campus (2014). One of the nine incentives included growing food on the campus.

Conservative anti-tax board members asked how sustainability would save money for the college and if it was just another word for environmental regulation. Some faculty members could not understand why they should revise the curriculum when doing so would only add to their already heavy workload. The Chief Financial Officer liked the idea of saving money on green energy but raised his eyebrows when I suggested that we consider "green" procurement policies. When I encouraged senior administrators to incorporate sustainability into their job descriptions they raised many objections. The Director of Advancement told me there was "no philanthropic potential in sustainability".

I am not exaggerating when I say that just about every sustainability initiative I suggested generated at least some doubts... at every stage I had to clarify why sustainability is important (especially for colleges and universities), how it is both a way of thinking and a way of life, and why it should be the foundation for how to conceive of service, civic engagement and the liberal arts. (p.4) 
The reservations described above regarding campus sustainability withdrew as the benefits of the green initiatives to the university, faculty, and student body became apparent. Unity College is now a global leader in the campus sustainability movement and models a holistic approach to campus food production.

In addition to rallying administrative support, Edible Campuses also rely on a desire for local food from the community it serves. Hendrix College (Arkansas) is a notable example in discussions regarding the durability of sustainable campus food projects. Gary Valen, Dean of Students, developed mutually beneficial relationships between local farmers and Hendrix College in the 1980s (Valen, 1992).

However, the farmer cooperative that provided Hendrix College and the surrounding community with cost efficient sustainable food no longer became viable as local food availability fell out of sync with the season of demand. Furthermore, turnover became an issue for the cooperative as Valen and other administrators with a similar ecological ethos left and the college focus shifted away from environmental concerns. Subsequently, the student body also became increasingly less interested in sustainable food practices said Mike Flory, Hendrix College dining services director. Flory captured the mindset of many consumers when stating, "Our student body wants strawberries in January" (Barlett, 2011, p. 103).

Most recent efforts to revitalize the cooperative took the form of Hendrix College successfully helping a farmer expand his meatpacking plant. Unfortunately, the plant was bought by a corporation that was in turn bought by a conglomerate that subsequently closed down the plant 
(Valen, 1992). The Hendrix story serves as a cautionary example to small alternative producers who want to create a sustainable business model. Even colleges and universities located in rural regions, like Hendrix College, that receive significant economic development from the sustainable food project are susceptible to pressures from the conventional agrifood system. Furthermore, alternative food systems are more vulnerable to disruption with inconsistent administrative and consumer support.

\section{Section II: Rationale for Edible Campuses}

\section{Ecological Issues}

Within promotional material for Canadian Edible Campuses, ecological action is often presented as the primary rationale for campus food production (Brock University, 2013; Clavin, 2011). Local food production lowers $\mathrm{CO}_{2}$ emissions by reducing food miles, strengthens farm to consumer relations and can spark future consumer decisions oriented towards ecological action. Barlett (2011) found that American universities made similar socio-economic claims in reference to their local sustainable food programs. Claiming that prioritized sales to local food producers through their programs ameliorate and even reverse the national trend to farm concentration, capital intensification, and contract production (p.103).

Additionally, several American universities highlighted farm labour injustices in the conventional system as a rationale for Edible Campuses (Barlett, 2011 p.104) though the actual term Edible Campus was not used. The Sustainable Agriculture Research and Education Program at the University of California, Davis, for example, describes labour issues and 
community problems attributable to conventional farming, advocating for "socially just and safe employment that provides adequate wages, working conditions, health benefits, and chances for economic stability" for agricultural labour (Barlett, 2011 p.104).

Inherent in these ecological arguments is recognition of the harmful impacts of sprawl and a vision for different urban and rural land uses.

Edible Campuses can also correspond with fair trade goals, however, the two are rarely complementary. An Edible Campus typically seeks to support its surrounding community. Whereas, the conventional goal of fair trade programs is to use revenue created by campus consumption to benefit farmers and communities in developing countries. The economic support from the post-secondary institution replaces anonymous market relations with closer and more mutually beneficial ties between producers and consumers (Fair Trade Colleges and Universities Toolkit, n.d.).

Fair trade within this context is a form of social sustainability. While fair trade programs are prominent on campuses, social sustainability is notably absent from campus sustainability evaluations. In 2008, the University of Wisconsin Oshkosh declared itself "the first U.S. Fair Trade University" ("UWO-1st Fair Trade campus in US — Sustainability", n.d.). Chancellor Richard H. Wells of the University of Wisconsin stated "Sustainability goes well beyond being 'green'... it includes social justice as well' (Barlett \& Chase, 2013 p. 244). 
Conventional industrial farming operations cultivate monocultures as opposed to permaculture farming. Monocultures describe the farming of a singular crop whereas permaculture gardening promotes biodiversity. Monoculture farming reduces soil integrity by eliminating insects and bacteria. Furthermore, monocultures use an increase of nonrenewable and harmful synthetic materials such as pesticide and herbicides. Monocultures also do not have ground cover plants which reduce water runoff and thus water waste. Finally, monocultures burn significantly more fossil fuel. Conservative estimates report that monocultures take ten calories of fossil fuel to produce 1 calorie of food energy. In essence, permaculture gardening harms an ecosystem. Whereas a monoculture disrupts, and in the case of colony collapse, even destroys the nature balance of an ecosystem.

The Edible Camus definition used within this research allows for ambiguity as to whether food production takes the form of a mono or permaculture. The argument could be made that if a large-scale Edible Campus cultivates monocultures, it does not support a sustainable food model. However, it would still operate as an alternative food model. In other words, being an alternative food model is not synonymous with one that is sustainable.

\section{Health Issues}

A critical driver of the sustainable food movement has been the growing awareness that current Canadian and American food consumption is a significant health issue. Food related health concerns not only have economic implications but will decline life expectancy for future generations (Druker \& Goodall, 2015; Pollan, 2008b). Our food, both natural and artificial, has become a subject of concern for activists and researchers. The Food for Health Initiative at the University of California, Davis has been a driver in Nutritional Science, utilizing an 
interdisciplinary approach to the study of obesity, nutrition, healthy food availability, organic farming, and industrial food production. Campus wellness programs are increasingly paying attention to increasing consumption of fruits and vegetables, lowered amounts of saturated and trans fats, and reductions in processed foods. In addition to nutritional content, food traceability has become a subject of concern for many Canadians as industrial farming and large-scale food production are more likely to have disease outbreaks and food contamination. Alternative food systems create close farmer to consumer relations creating an increase in accountability and transparency (Druker \& Goodall, 2015).

Some Edible Campus rationales published on university/college websites point to research showing the higher nutritional content of organic or sustainably grown foods as well as improved taste. Although, claims to a higher nutritional content are still controversial among nutritionists and schools of agriculture (Druker \& Goodall, 2015). Brown University supports local purchases for "higher quality foods whenever and wherever possible" and to provide "fresher and healthier options" (Barlett, 2011 p.105). The University of California, Santa Barbara lists as its long-term goal "foods without additives, pesticides or preservatives" ("Food Actions | UCSB Sustainability", n.d.). Bowdoin College, Massachusetts states that "local-grown is fresher, of higher quality, and nutritionally superior" ("Bowdoin Dining Services", n.d.).

In sum, part of the rationale for Edible Campuses as presented by universities and colleges is a concern for healthy eating and a distrust of conventional food channels as well as support for alternative systems (NASPA: Student Affairs Administrators in Higher Education, 2010). However, rarely do rationales advocate explicit political goals and national or global policy 
changes. Edible Campuses offer an opportunity to legitimize consumer concerns that coalesce with social and political food and environmental movements.

\section{Alternative Food Systems}

An alternative food system can be understood broadly as food produced outside of the conventional industrial food system for the purpose of serving a community. Alternative food systems can take the form of civic agriculture which is widely praised for its ability to supply local food shelters, strengthen farmer-consumer relations, and create more transparency through production, distribution, and consumption (Hassanein 2008; Lyson, 2004). Edible Campuses often act as alternative food systems as they produce food that is distributed within the campus community and/or local population.

Hassanein (2008) and Goodman, Goodman and Dupuis (2014) examined campus food production within a broader discussion on the merits of alternative food systems. Both research teams independently came to the conclusion that campus food production initiatives are capable of acting as incubators for pioneering new nodes in an alternative food system. Gliessman (2013) examined alternate food sources for their ability to have a significant political and economic impact on agricultural food systems. Gliessman (2013) concluded that alternative food systems are the form of food sourcing that would be most beneficial to sustaining future generations and the planet.

As previously discussed in Section 1 (Opposition to Edible Campuses), the economic reality of alternative food systems has been called into question. Research conducted by 
Thomas Lyson and Clare Hinriches, in Remaking the North American Food System:

Strategies (2007), dispelled many of the misconceptions of the economic practicality of alternative food systems, particularly concerning campus food production. Gibson-Graham (1997) wrote that an institution that creates new distribution and supply chain nodes can enable local sustainable purchasing at lower costs. Furthermore, Barlett (2011) believes that "If campus leadership enforces goals and if school rankings on green practices continue to gain a foothold, local efforts can stimulate new 'business models' for institutional food provision" (p.108).

\section{Section III: Sustainability in Higher Education}

The 2015 United Nations climate negotiations (COP21) in Paris set the direction to limit $\mathrm{CO}_{2}$ emissions to prevent temperature increases over the upcoming decades. These policies not only set in motion green initiatives and laid the groundwork for future policy, but marked a momentous event as it was the first time world leaders came together to collectively enact concrete policy in regards to $\mathrm{CO}_{2}$ emissions. Subsequently, the global demand for environmental action was echoed at the World Economic Forum (2016) where the International Sustainable Campus Network (ISCN) in collaboration with the Global University Leader Forum (GULF) shared a report on the best practices for sustainable campuses. The ISCN report (2016) endorsed the 17 Sustainable Development Goals (SDGs) that were later adopted by all 193 member states of the United Nations in 2017. 
Despite the momentous milestones of the COP21 and global acceptance of the 17 SDGs, René Schwarzenbach, ISCN Board President, and Guido Schmidt-Traub, Executive Director, Sustainable Development Solutions Network (SDSN) stated that:

It is time for the academic community to seriously rethink and redefine its role in society and in sustainable development efforts. The global higher education sector has a tremendous opportunity to lead the world in sustainable development research, promotion of solutions, and support for implementation. (Vickery, 2017)

The ISCN presented at the 2017 World Economic forum a report highlighting global case studies of exemplary campus sustainability, including campus food production conducted by leading universities worldwide. The report concluded that universities around the world, many of them members of global networks such as ISCN, SDSN, GULF and International Alliance of Research Universities (IARU) "urgently need to strengthen their efforts to solve the pressing problems of this planet" (Vickery, 2017).

The ISCN (2017) report found that universities' support for sustainable development has primarily focused on campus design and operations. Thus, less attention is given to solutionsoriented research, related policy challenges, or practice-focused education of students. The ISCN report argues that more than ever "holistic and cross-disciplinary initiatives are needed to link academic and operational excellence into a truly sustainable learning environment and experience. Solutions-oriented sustainability research will require more inter- and trans- 


\section{Growing An Edible Campus}

disciplinary approaches" (p.3). Edible Campuses fit within the needs and goals put forth by the ISCN (2017) report.

Gibson-Graham (2006) makes the argument that campus food is an ideal entry point for positively disrupting the local food chains due to its "economic clout, corporate connections, and emotional resonance with family traditions, place, and identity" (p. 187). The implication being that institutions of higher education are in positions of privilege with a responsibility to practice and raise awareness about the necessity of a sustainability ethos. Dr. Mitchell Thomashow, President of Unity College (mentioned previously), furthers this point by articulating how campuses are the ideal setting for exploring and practicing sustainability:

Colleges and universities offer the best hope for raising awareness about the climate crisis and other environmental threats. They provide opportunities for both research and implementation; they have the capacity to engage, students, staff, and faculty in collaborative enterprises that inspire campus transformation; they take the idea of legacy seriously. (2014, p.8)

The belief that universities and colleges have both a responsibility and an ideal setting for modelling sustainability was reflected in The Climate Leadership Commitment ("The Presidents' Climate Leadership Commitments", 2017). The Climate Leadership Commitment was enacted in 2007 and has been signed by over 600 American university and college presidents. The act was created as a response to an audit that pointed to universities and colleges as major contributors to greenhouse gasses from food production and transportation. Furthermore, over 500 university 
leaders in 50 countries have formally committed to environmental sustainability in higher education through the Talloires Declaration ("Talloires Declaration - ULSF", 2017).

\section{Educational Reform}

Food production is steadily being addressed within scholarly discussions of educational reform (Association for the Advancement of Sustainability in Higher Education, 2017). The urgency of educational reform oriented towards environmental action is perhaps best understood through a 2005 UNESCO report. The UNESCO report asked when working towards a sustainable future, "is education the problem or the solution?" (2005, p. 57). The report came to the disheartening conclusion that "at current levels of unsustainable practice and over consumption, education is part of the problem" (p. 57). The report recommended that if education is to become part of the solution, a redesign of the whole system is needed "to challenge existing frameworks and shift our thinking beyond current practice and toward a sustainable future" (p. 57). O’Brien and Howard (2016) have proposed that Living Schools have the capacity to accelerate education reform within a vision of well-being for all (Hopkins, 2013). In their view, a living school or living campus integrates sustainability, with experiential learning and new pedagogies such as a real-world project-based learning. Edible Campuses reflect many of the attributes of a Living School (Howard \& O’Brien, 2017).

Following the publication of the 2005 UNESCO report, leaders in environmental sustainability and education have identified the relationship between food and education to be critical in creating a more sustainable future (Despommier, 2011; Lappé \& Collins, 2015). However, as the UNESCO report suggests, simply adding food into the curriculum is not enough to establish a 
culture of sustainability nor to transform education. Rather, as O’Brien and Murray (2017) suggest, we can transform ourselves and education through food. This may involve, for instance, a co-learning inquiry of students and staff/faculty regarding their relationship with food, establishing various edible projects that are integrated with curricula, conducting action research that influences campus policy and practice, and possibly even supporting the development of entrepreneurial food-related ventures.

More than a decade ago, Price and Gottlieb (2002) and Watson (2002) noted that campus food production initiatives contribute to more critical perspectives on the industrial food system and raise the possibility of incorporating long term social and environmental concerns into public policy. Barlett (2011) holds a similar view and writes that "the intent and capacity to foster cultural change can be found in both academic programs and experiential learning in sustainable food projects" (p.108).

\section{Section IV: Gaps in Evaluation Frameworks and Guidelines}

Despite the growing popularity of Edible Campuses, there are currently no assessment or evaluation tools for campus food production systems. Resources have been published to assist students in the initiation of campus gardens, and farmers have resources from governments and agricultural organizations to guide and evaluate their businesses. However, a comprehensive evaluation framework for Edible Campuses must incorporate more indicators than those identified by the existing literature. This section will provide an overview of evaluation 
frameworks for sustainability and well-being in education, agriculture and student-run gardens that could provide direction for assessing Edible Campuses.

\section{Evaluating Sustainability and Well-being in Education}

Frameworks already exist to measure sustainability and well-being in institutions of higher education that could be used as a frame of reference for evaluating Edible Campuses, explicitly making the connection between sustainability and well-being for all (Hopkins, 2013). For instance, the Sustainability Tracking, Assessment and Rating System (STARS) (2017) is a widely used tool within Canada and the United States for evaluating sustainability in postsecondary institutions. STARS claims to be "a transparent, self-reporting framework for colleges and universities to measure their sustainability performance" (FSU Sustainable Campus Initiative, 2011, p.5). Created by the Association for the Advancement of Sustainability in Higher Education (AASHE), STARS provides a set of comprehensive evaluation criteria for awarding credits for sustainable practices in all facets of university operations. The STARS method is essentially a checklist of sustainability practices with established scores that are totaled to arrive at a rating. One of the goals for this method is to create a scoring system that could be used for promotional material (FSU Sustainable Campus Initiative, 2011). STARS does not use the term Edible Campus. Universities earn an almost insignificant 0.25 credit for "the presence of an organic garden on campus where students are able to gain organic farming and/or gardening experience" (AASHE, 2017, p.18). STARS appears to be a very limited sustainability indicator approach when we consider the diversity of Edible Campuses and their qualitative impact which cannot be captured through a strictly quantifiable score. 
In contrast, frameworks such as the Sierra Youth Coalition's CSA (Community Supported Agriculture) assessment (2017) also includes health and well-being. At the K-12 education level

there are frameworks that support institutions to identify areas for further growth with respect to sustainability (Government of Ontario, 2017) or health and well-being (Pan-Canadian Joint Consortium for School Health, 2017). Though, as mentioned previously, in the case of the Positive Mental Health Toolkit, positive mental health is not addressed with reference to sustainability Campus sustainability audit research in Atlantic Canada: pioneering the campus sustainability assessment framework (Beringer, 2006). My searches did not reveal a comparable framework for post-secondary institutions, one which would integrate sustainability with individual well-being. I posit that an even more ambitious campus sustainability framework would capture well-being for all (Hopkins, 2013; O’Brien, 2016). K-12 frameworks do not focus on adult learners and engage with a significantly different learning environment than postsecondary institutions. However, as Edible Campuses are an emerging area of research the evaluation frameworks from public education can be recognized as a foundation for the development of an Edible Campus evaluation framework.

\section{Agricultural Evaluations}

Agricultural evaluation can also be used as a starting point for evaluating Edible Campuses.

Canadian Agricultural Ministers have created numerous resources for evaluating both urban and rural agriculture case studies (e.g., BCMAL, 2017; ATTRA, 2017). The majority of these agricultural evaluations focus on self-assessment to determine areas of growth and progression. From the self-assessment farmers use a template to create a plan of action. Some of the themes used in farm evaluations are directly applicable to on-campus food production initiatives, while 
others can be modified to more appropriately match the university context. For example, the nine categories used in Taking Stock: A Farm Business Planning Workbook For The Beginning

Farmer (BCMAL, 2017) are:

1. Business Strategy

2. Marketing Strategy

3. Production Economics

4. Human Resources

5. Financial Management

6. Social Responsibility

7. Succession Planning

8. Business Structure

9. Risk Management

The self-assessment questions highlight important concepts in production economics, risk management, and succession planning, such as dependency on key members and contingency plans. In the farm context, succession often refers to family members; while families are not the key players in campus farms and gardens, succession and turnover are issues that are relevant to a student-run or volunteer-run Edible Campus. This could also intersect with social responsibility as some Edible Campus projects are used to produce food for local community organizations. If those organizations come to depend on the food and the edible project is not maintained, this could lead to challenges for the community it previously served.

Guides for Student-run Food Production 
"Colleges and universities are leading the sustainable food movement and have been for awhile" states Roberta Anderson of the Food Alliance (Barlett, 2011, p.108). One of the products of that leadership is The Real Food Challenge. The Real Food Challenge is an organization that "maintains a national network of student food activists_-providing opportunities for networking, learning, and leadership development for thousands of emerging leaders" (Real Food Challenge, 2017, p.7). The Real Food Challenge created a guide to aid students in maintaining or creating campus food production projects. The Garden Guide "focuses on how to establish a small-scale garden at your college" (The Garden Guide, 2010, p.4). The Garden Guide is similar to the Bon Appétit Management Company (2017) in that it provides basic guidance through Student Gardens and Food Service (2009), a document created "to help student gardeners establish a successful relationship between your campus food service team and your student garden" (p. 3). Both guides address the importance of planning, communication, production logistics, and promotion for student-run gardens, as well as suggestions on building relationships and improving the garden every year.

The Co-operative Food Empowerment Directive created the CoFed Manual for Starting StudentRun Food Cooperatives (2011) that provides students with the tools to distribute food but not source it. Similarly, Oatfield's Best Practices for Starting Sustainable Food Cooperatives in University Communities (2010) does not assist students with evaluating, creating or governing the Edible Campus.

\section{Urban Agriculture}

Urban farmers can increasingly be found on the campuses of metropolis-based post-secondary institutions. The urban food movement has spawned innovative solutions to tackle problems 
related to growing food in congested cities. Urban agriculture is hardly a new concept. Food, to some degree, has always been grown within an urban environment. However, prior to the 1990's urban agriculture was almost exclusively discussed amongst academics. Following the 1992 United Nations Conference on Environment and Development (UNCED) the concept of urban agriculture was formally recognized as the subject of research, public policy and city design. The UNCED, or Earth Summit as it came to be known, led to the creation of a comprehensive document, Agenda 21 (United Nations [UN], 1993), that encouraged local governments to engage with sustainable design, jump starting policy and further research on urban agriculture.

Urban Edible Campuses that work to incorporate the surrounding community have been identified as effective models for promoting urban sustainability (Holland, 2004). However, Turner (2011) warns that any further development into the role community gardens can play in urban sustainability must "factor in the individual and (his/her) motivations and desires, not just those of an imagined Canadian Food Studies and the Canadian Review of Arts broader collective" (p. 514).

Urban Agricultural case studies can be used as a source of inspiration for both urban and rural Edible Campuses. Space limitations often lead urban farmers to form innovative solutions for harvest space, water sourcing and waste management. A full review of urban agriculture scholarship goes beyond the scope of this thesis. However, to name a few texts for further reading: Carrot City (Gorgolewski, Komisar, \& Nasr, 2011) is a text out of Ryerson University that features global case studies of urban agriculture, including Edible Campuses. The Vertical Farm: Feeding the World in the 21st Century (2011) invites the reader to imagine growing 'up' 
instead of 'out.' The Vertical Farm offers an answer to the question posed by leading scholars in environmental sustainability and food sourcing, ‘how do we feed our growing population'? (e.g. Lappé, 1985, Lappé, 2010; Lappé, \& Lappé, 2005; Foley, 2014). Farm City (2009) is a biographical account of one urban farmer who grew food and cared for livestock on an unclaimed lot in the inner city of Oakland. Food and the City by Cockrall-King (2012) examines how urban agriculture initiatives, including campus food production fit within the framework of alternative food systems around the world. Peter Ladner, who served two terms as a Vancouver City Councillor challenges the reader to rethink how we feed our cities in The Urban Food Revolution (2011). Ladner highlighted education as a critical point in need for change and provided a FAQ section as an easy starting point for someone newly interested in urban agriculture. The Edible City: Toronto's Food from Farm to Fork is a collection of 40 essays assembled and edited by Palassio and Wilcox (2009). Farm to Fork is a superb text for referencing a broad spectrum of opinions on Canadian urban agriculture.

\section{Section IV: Summary}

A common theme amongst the diversity of literature discussed in this review is a lack of recognition for the importance of social sustainability. Social sustainability incorporates a broad range of concepts, including well-being, quality of life, social interaction, sense of community, and sense of place (Williams \& Forbes, 2012). Ghahramanpouri, Lamit \& Sedaghatnia (2013) have defined it as "a positive, life-enhancing condition within communities" (p. 12). Furthermore, the attainment of social sustainability involves "a process for creating sustainable, successful places that promote wellbeing, by understanding what people need from the places they live and work" (Woodcraft, Hackett, \& Caistor-Arendar, 2011 p.16). 
While student well-being is presented as a priority by the Campus Population Health Promotion Model and the UK Healthy Universities Model ("Developing a Population Health Promotion Model", 2017; "Model \& Framework for Action - Healthy Universities", 2017), a noteworthy absence of these frameworks is the well-being of staff, faculty and community. Additionally, few well-being frameworks make the association to ecological well-being. However, food sustainability programs can improve collective well-being (D’Abundo \& Carden, 2008). Edible Campuses, as evident from this literature review, can promote well-being for all, including future generations. Lau \& Yang (2009) bring D’Abundo \& Carden's research into a practical application by detailing how to design gardens on small campuses. Lau \& Yang describe the addition of a garden to a campus as "healthier, sustainable and healing” (p.1).

Williams and Forbes (2012) add to this idea when stating, "if sustainability is to be more than an abstract idea, it must address the spirit of communities by speaking about what matters to them" (p. 116). Edible Campuses need to reflect the pluralism and diversity of the community that they serve. Given this, we might ask what are the barriers and future goals identified by individuals who create, governing maintain Edible Campuses? Subsequent chapters will address this question. 


\section{Chapter Three}

\section{Methodology}

\section{Research Objectives}

In addition to the development of the Edible Campus database, this research has three key objectives: 1) to develop an overview of the diverse ways food production on Canadian postsecondary campuses is cultivated; 2) to analyze and quantify common themes related to barriers and goals that are identified by Edible Campus teams; and 3) to compare the benefits of Edible Campuses as identified by Edible Campus teams to the literature that supports and opposes the value of Edible Campuses.

From these three key research objectives we can piece together what the future of Edible Campuses could look like as a platform for research, education and as an alternative food system. The ECD enables future collaborations between Edible Campus teams thus translating the scholarly discussion of Edible Campuses into practical action.

\section{Phase One: Edible Campus Database}

The ECD was created with inclusion in mind and is continuing to grow through referrals at the time of writing. The database represents Edible Campuses across Canada as defined by this research:

An Edible Campus describes food production on the campus of postsecondary institutions. While campus food production is often cultivated in under-utilized spaces such as rooftops, it can also take 
place in a multitude of locations such as classrooms or greenhouses.

Campus-based food production, sustainable campus, community

gardens, civic agriculture and living schools are terms that are often

associated with an Edible Campus and can be included within this

definition.

Meal Exchange is a nonprofit organization located in Toronto Ontario. Meal Exchange provided a portion of the Edible Campuses database. Similarly, the Carrot City database was also a contributor. The Edible Campuses database was largely developed by referral and Internet searches.

Keyword search phrases:

$\begin{array}{lll}\text { Campus Garden } & \text { Community Garden } & \text { Gardens } \\ \text { Campus Farm } & \text { Campus Rooftop Garden } & \text { Canadian College Farm } \\ \text { Canadian Campus Garden } & \text { University Gardens } & \\ \text { Canadian Campus Farm } & \text { University Farms } \\ \text { Campus Community } & \text { College Gardens } \\ \text { Garden } & \text { College Farms } \\ \text { Canadian Campus } & \text { Canadian University }\end{array}$


The ECD currently has over fifty examples of campus food production initiatives. The database indicates the location, size and start date of the Edible Campus as well as if it is student run and/or student managed. The database was developed with the intent of encouraging an exchange of information within the sustainable campus community.

\section{Distributing the Edible Campus Database}

The ECD will be distributed through the campus sustainability network developed by Meal Exchange. Meal Exchange will receive a copy of the ECD as a Microsoft Excel spreadsheet so that it can be updated as needed. Furthermore, the ECD will be distributed to research participants who indicated they would like a copy of the database at the conclusion of the survey. Due to the comprehensive size of the ECD it is not included in full within this research document. Participating universities and colleges can be found below in Table 1.0.

\section{Growing the Edible Campus Database}

The ECD was developed in part through a snowball sampling methodology. Snowball sampling works through referrals and builds momentum over time. In the case of this research, within the recruitment letter potential research participants were asked if they were aware of similar campus food production projects within Canada. The projects named which met the criteria of an Edible Campus as proposed by this research were also sent a recruitment letter and invited to name similar projects. Some individuals who were not available to participate in the survey still contributed to snowball sampling. The Edible Campus survey also concluded with a section to name additional Edible Campuses. 


\section{Phase Two: Edible Campus Survey}

The ECD was the foundation for the pool of potential research participants.

An email was sent to the primary contact for the respective Edible Campus inviting a member of the team to participate in the survey. The recruitment email [Appendix 1] was titled "Invitation to Campus-based Food Production Research" which initially created confusion for some participants who responded inquiring if campus-based meant campus-run. The individuals interested in participating were sent a consent agreement [Appendix 2] to be signed and returned. Following the return of the consent agreements participants received the survey [Appendix 3] with an identification number.

The surveys did not include any questions that would reveal the participant's identity. Francophone participants were encouraged to respond to the survey in their preferred language. The survey itself was not translated. One participant completed the survey in French. The twenty-one participating post-secondary institutions are listed below as Table 1.0 in order from Canada's east coast provinces towards the western provinces.

Table 1.0: Participating Post-Secondary Institutions

\begin{tabular}{|c|c|c|}
\hline Post-secondary Institution & Location & Name of Edible Campus \\
\hline Cape Breton University & Sydney, Nova Scotia & CBU Community Garden \\
\hline Acadia University & Wolfville, Nova Scotia & Project \\
\hline & & Acadia Community Farm \\
\hline
\end{tabular}




\begin{tabular}{|c|c|c|}
\hline Dalhousie University & Halifax, Nova Scotia & $\begin{array}{l}\text { Dalhousie Agriculture } \\
\text { Campus Chef's Garden }\end{array}$ \\
\hline Mount Allison & Sackville, New Brunswick & Mount Allison Farm \\
\hline Dawson College & Montreal, Quebec & Dawson Gardens \\
\hline $\begin{array}{c}\text { Université du Québec à } \\
\text { Montréal }\end{array}$ & Montreal, Quebec & $\begin{array}{l}\text { Le CRAPAUD (collectif de } \\
\text { recherche en aménagement } \\
\text { paysager et en agriculture } \\
\text { urbaine durable) }\end{array}$ \\
\hline McGill University & Montreal, Quebec & $\begin{array}{l}\text { D.I.G. (Develop Integrate and } \\
\text { Grow) Community Garden }\end{array}$ \\
\hline University of Montreal & Montreal, Quebec & $\begin{array}{l}\text { PAUSE (Production Agricole } \\
\text { Urbaine Soutenable et } \\
\text { Écologique) }\end{array}$ \\
\hline Guelph University & Guelph, Ontario & $\begin{array}{c}\text { Guelph Centre for Urban } \\
\text { Organic Farming }\end{array}$ \\
\hline York University & Toronto, Ontario & $\begin{array}{l}\text { York University's Maloca } \\
\text { Community Garden }\end{array}$ \\
\hline Ryerson University & Toronto, Ontario & Ryerson Urban Farm \\
\hline University of Waterloo & Waterloo, Ontario & $\begin{array}{l}\text { North Campus Community } \\
\text { Garden }\end{array}$ \\
\hline Brock University & St. Catharines, Ontario & $\begin{array}{l}\text { D.I.G. (Develop Integrate and } \\
\text { Grow) Community Garden }\end{array}$ \\
\hline
\end{tabular}




\begin{tabular}{|c|c|c|}
\hline Algonquin College & Nepean, Ontario & $\begin{array}{l}\text { Algonquin College } \\
\text { Community Garden }\end{array}$ \\
\hline Confederation College & Thunder Bay, Ontario & $\begin{array}{l}\text { Confederation Community } \\
\text { Garden }\end{array}$ \\
\hline University of Windsor & Windsor, Ontario & Campus Community Garden \\
\hline University of Regina & Regina, Saskatchewan & The Green Patch \\
\hline University of Saskatchewan & Saskatoon, Saskatchewan & $\begin{array}{l}\text { 1. Local Fruit Garden } \\
\text { 2. University of } \\
\text { Saskatchewan Horticulture } \\
\text { Club vegetable plot } \\
\text { 3. Rooftop Garden }\end{array}$ \\
\hline University of Alberta & Edmonton, Alberta & $\begin{array}{l}\text { Green and Gold Community } \\
\text { Garden }\end{array}$ \\
\hline $\begin{array}{c}\text { Okanagan College (Vernon } \\
\text { Campus) }\end{array}$ & Kelowna, British Columbia & $\begin{array}{l}\text { 1. Patchwork Farms } \\
\text { 2. Kalamalka Garden }\end{array}$ \\
\hline $\begin{array}{l}\text { University of British } \\
\text { Columbia }\end{array}$ & Vancouver, British Columbia & $\begin{array}{c}\text { Centre for Sustainable Food } \\
\text { Systems at UBC Farm }\end{array}$ \\
\hline
\end{tabular}

The survey questions were developed with the diversity of Edible Campuses in mind. Questions sought to both celebrate the uniqueness of the Edible Campuses while also seeking out common themes. The participants often had the opportunity to elaborate on a response within a comment 
box. Participants could also decline to answer any question and participant identity was kept confidential.

\section{Framework for Analysis}

This research employed mixed methods to analyze the survey results. The first phase was a quantitative survey analysis of the multiple choice responses. The second phase was a qualitative discourse analysis on the text responses that elaborated on the multiple choice options. The qualitative analysis has the benefit of studying the relationship between categories or correlations between variables found during the quantitative analysis. The qualitative discourse analysis creates a multidimensional description and explanation of the diversity of Edible Campuses. The perspective the research participants have as members and/or creators of Edible Campuses cannot be captured through a purely quantitative analysis. The quantitative method balances the qualitative by generating a significantly less biased depiction of Edible Campus. The form of the multiple choice questions commands objective responses allowing for an easily quantifiable analysis.

\section{Quantitative Approach}

The quantitative method involved scanning the surveys and noting themes that were reoccurring. Each theme was developed to be unambiguous, mutually exclusive and exhaustive so that any response was filed into a singular category. The frequencies of the categories were noted and cross-tabulated. Text passages were taken into account during the second, qualitative phase of data analysis. The criteria for cross tabulation was developed with the intent of creating an accurate depiction of Edible Campuses from the perspective of the research participants. The 
suitability of the subcategories was formed based on: themes presented in the literature review, compensation for non-responses, quality of data entry, and metadata recording.

\section{Qualitative Approach}

The second phase of analysis used a non-experimental one-shot survey qualitative method to examine the written responses from the participants. Several hypothesizes were formed after reviewing the data collected. Informed by these hypotheses the data was sampled accordingly. This is the logic of both grounded theory in developing and saturating concepts and analytic induction in developing and testing hypotheses. When presenting the data, percentage was rounded to the highest number. It is important to note that due to the fact that participants could opt out of survey questions the percentages presented in the findings chapter represent responses not a division of participants. For example, if a graph that shows $50 \%$ of participants believe X, $50 \%$ represents the participants who responded to the question not $50 \%$ of all participants in the research.

\section{Methodological Limitations}

The intent of this research is to represent the practices of Edible Campuses throughout Canada. However, post-secondary institutions located in northern Canada did not participate in this study. Despite an extensive search only one institution from northern Canada was found to have an Edible Campus. The northern institution was non-responsive to the invitation to participate. The minimal northern Edible Campus data could stem from less media attention making evidence of northern Edible Campuses more difficult to find. Or perhaps, northern weather conditions make 
food production costlier and thus less common. Nevertheless, eight of ten Canadian provinces participated.

The ECD will be updated as needed by Meal Exchange, allowing the database to continue to grow so perhaps northern Edible Campuses will be added in the future. Future research into Edible Campuses could be specific to northern Canadian campus food production. I hypothesize that northern Edible Campuses will likely overcome unique challenges not faced by the participants of this research.

A second methodological limitation is that the sampling of qualitative responses is biased to my choice of text selection. While my intent was to accurately represent the reoccurring themes within the text responses I cannot fully remove myself from the research.

Finally, the Ryerson University ethics review process created unforeseen challenges. The Ryerson University ethics review board first requested ethics approval from all participating universities and colleges. As this request went beyond the time restrictions of a Masters research project an alternative solution was proposed and accepted. Individual ethics applications for each participating university and college would require more time than allowed for the competition of a Masters thesis by the Communication and Culture program at Ryerson University. Language within the consent agreement and recruitment email was carefully selected and a disclaimer on the title page of this research was added [see Appendix 1]. These revisions were included so that participant responses clearly reflect individual opinion and not the opinion of their associated post-secondary institutions. 


\section{Chapter Four}

Analysis
Section I: Participating Edible Campuses Overview:

Size of Edible Campuses

The size of the Edible Campuses included within this research is measured in square acres. Fifty percent of the twenty-one participating universities and colleges have a form of food production from 1501 square acres to 3,000 and over square acres. From these results [see Figure 1.0] we can recognize that the image of small campus gardens or pilot projects as depicted in the literature review, no longer reflects the norm of the current Canadian campus food production. 
Figure 1.0: Size of Edible Campuses

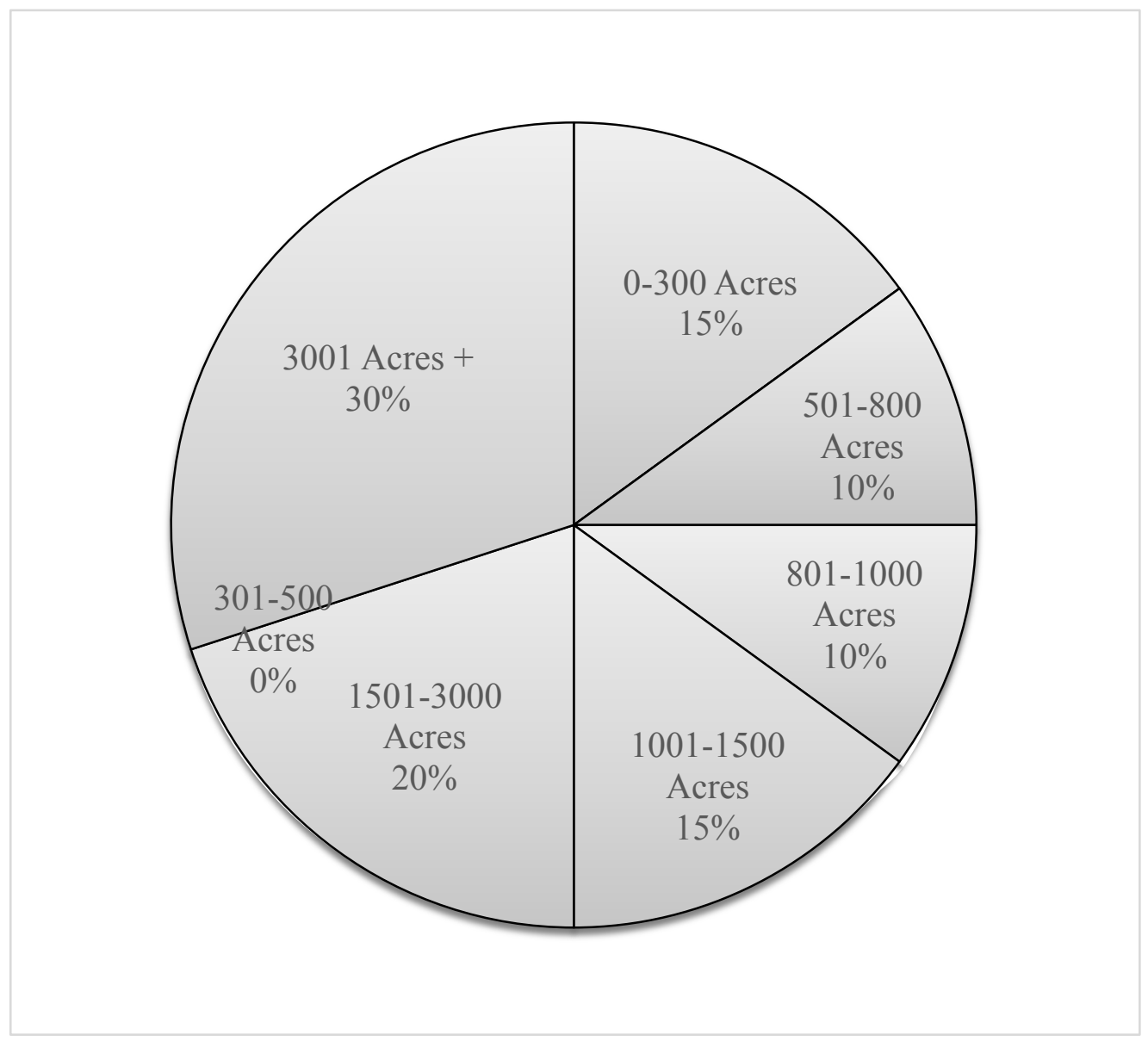

Funding the Edible Campus

Participants were asked in a multiple choice format: "What was the estimated income of your

Edible Campus last year, including income from funding sources and revenue?" [See Figure 2.0]. 
Growing An Edible Campus

Figure 2.0: Income of Edible Campuses

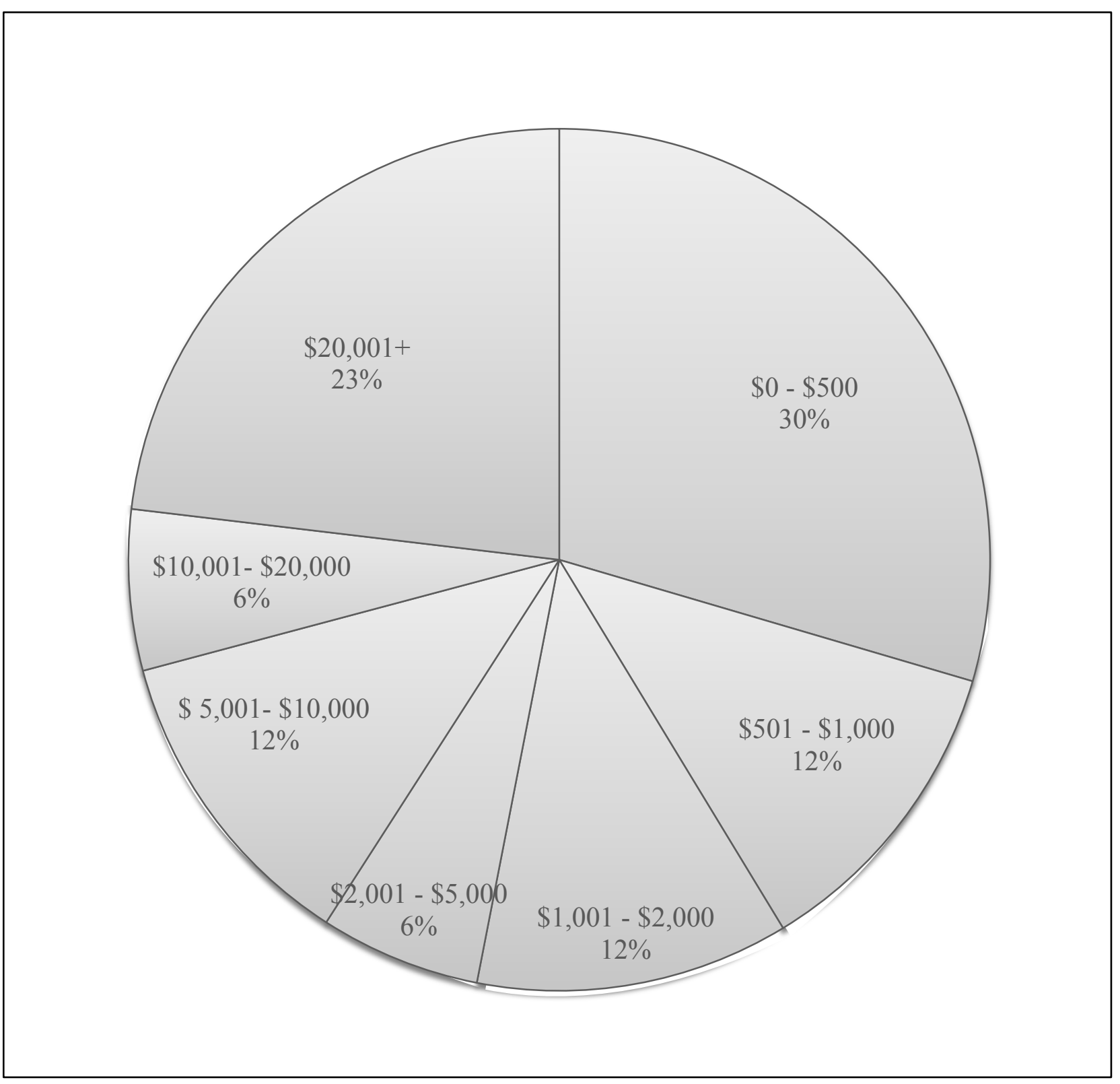


The question regarding the estimated income of Edible Campuses had a low response in comparison to the question regarding the size of the Edible Campus. Thus a simple, visual comparison of Figures 1.0 and 2.0 does not represent an accurate analysis of size and income. The correlation between income and size was analyzed by tallying and cross tabulating the two datasets, size and income.

Participants were asked to name both past and current funding sources [see Figure 3]. The participants were given a list of multiple choice answers with the option to choose 'other' and name an additional source or include additional detail. Participants could choose multiple funding sources.

The $12 \%$ of respondents that chose 'other' often stated that their funding stemmed from nongovernment grants or from individuals who rented garden plots. Almost all respondents indicated more than one funding source. 
Figure 3.0: Funding Sources

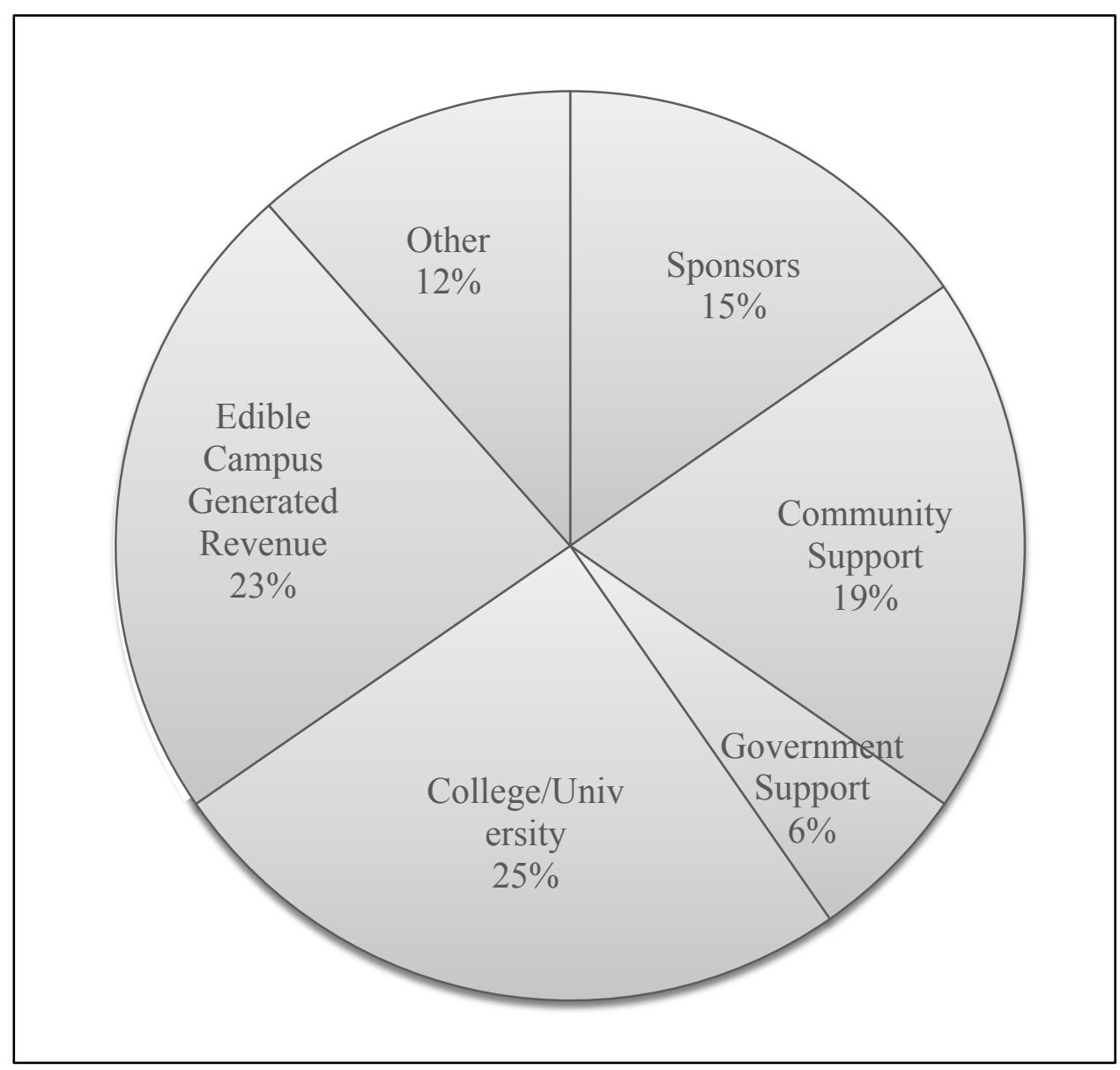

\section{Spaces Edible Campuses Occupy}

Participants could choose multiple options with the option to select 'other' and provide additional detail. The participants who responded "other" and elaborated further described a 
diversity of growing areas including, soccer fields, greenhouses, ground level rooftops,

\begin{tabular}{|r|r|r|r|}
\hline Rooftops & & & \\
Cape Breton University \\
Acadia University \\
Dalhousie University \\
Mt. Allison University \\
Dawson College
\end{tabular}

workshops and sprout production in corridors.

Figure 4.0: Spaces Edible Campuses Occupy 


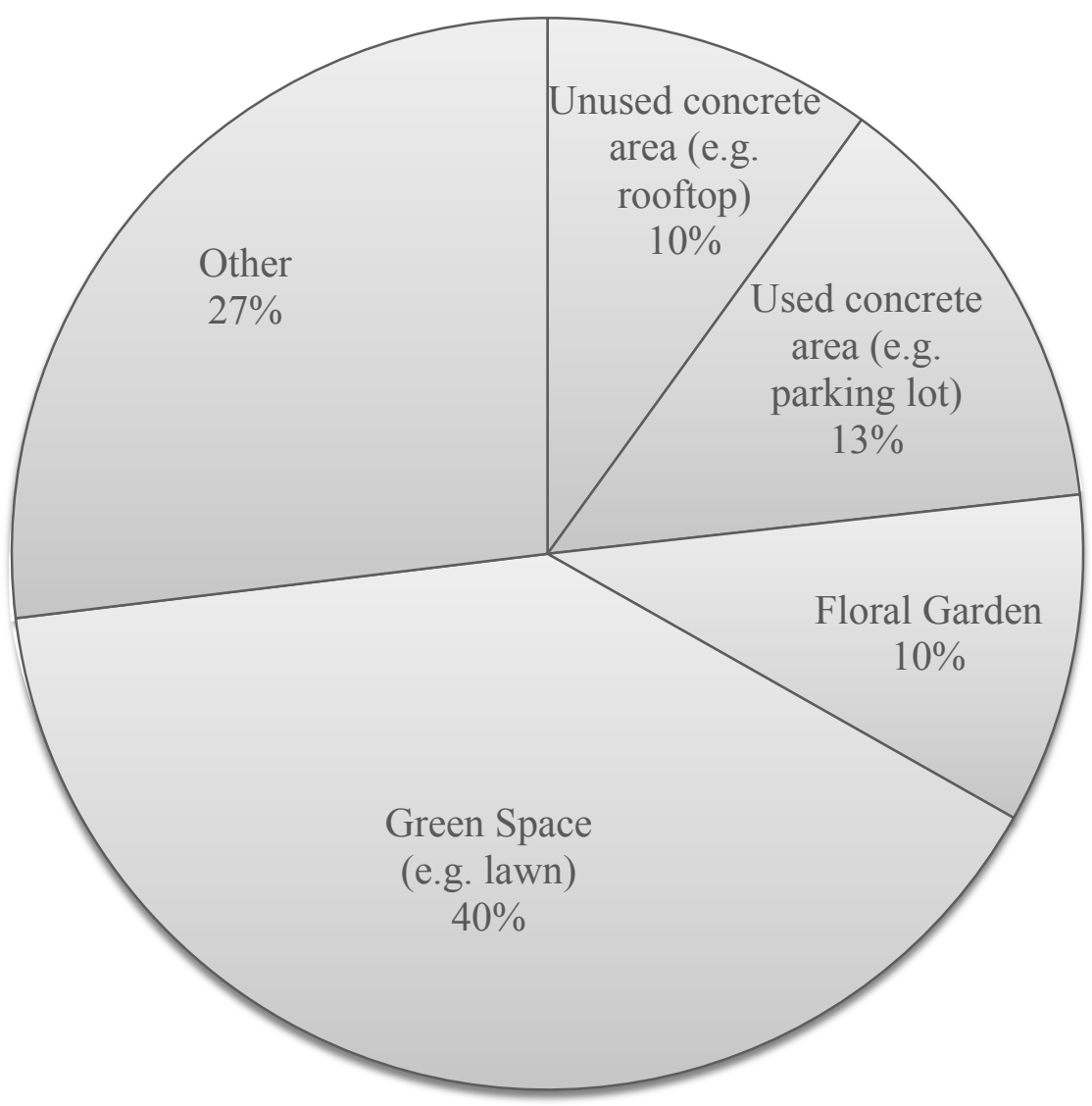

Participants were asked: "How was the Edible Campus location utilized prior to the food production?" [see Figure 5.0]. Respondents were able to select multiple choices and provide additional detail.

Figure 5.0: Past Uses for Edible Campus Spaces 
Themes among the respondents who chose 'other' were: greenhouses and/or underused research garden plots. By contrasting how the location of the Edible Campus was utilized prior to food production to the spaces the Edible Campuses occupies we can get a sense of the transformative benefits campus food production has on post-secondary institutions.

When asked if the Edible Campus was used for research, $61.9 \%$ said yes. Among respondents who did not used their Edible Campus for research $50 \%$ saw it as a future goal. The Edible Campus was used as a platform for education by $90 \%$ of respondents. All respondents who do not currently use their Edible Campus as a platform for education saw it as a future goal.

One of the questions this survey sought to answer was if Edible Campuses shared learning processes. When asked if the Edible Campus has "used designs from another Edible Campus or 
urban agriculture project" only $22.2 \%$ of respondents said yes. When asked if their Edible Campus has "led to the creation of any environmentally sustainable design projects" $50 \%$ said yes. $82.3 \%$ of respondents indicated that they chose plants with other species in mind.

\section{Section II: Qualitative Responses}

\section{Identifying Barriers to Growth}

When research participants were asked "What administrative or policy barriers do you believe exist which deter developments of Edible Campuses?", a common theme among the respondents was a lack of financial support from the associated post-secondary institution. Below is an excerpt from two respondents:

1) 'Universities' understanding of the importance of Edible Campuses. Lack of funding. It's not the priority of many universities' administrations."

2) “...lack of support (financially, resources) to start. No one to administer the garden."

When asked "what are the obstacles your Edible Campus had to overcome?", within a multiple choice format, $29.5 \%$ of respondents chose receiving funding. A west coast respondent communicated risk of seeking financial support outside of higher education:

The Farm receives funding from the local municipality. The contract for this funding does not allow for developing an enterprise model for 
the Farm. A choice between accepting the funding and community garden status or creating a profitable farm is a difficult choice for the non-profit organizations involved due to the risk of starting a small agricultural business without any government support.

In addition to the lack of financial support other respondents communicated a perceived limited commitment to sustainable practices by the associated post-secondary institution. The excerpts below from two research participants echo these themes:

1) Our admin[istration] wants any expense to be tied to teaching needs; limited commitment to sustainable local food and the extra costs associated with that.

2) A key barrier to challenging the way we think about the purpose of a campus and campus grounds overall is that a genuine sustainability agenda is not on the radar/agenda/priority list for some folks in administration or facilities. I am on a sustainability committee and we have had many challenges in getting a sustainability policy accepted by the university.

A common theme among $22 \%$ of the participants who indicated 'other' in response to the "what barriers has your Edible Campus overcome" question was a perceived lack of understanding from the university or college on the importance of the Edible Campus. Some 
respondents wrote in the present tense, suggesting this is still a barrier they have to overcome. A Quebec respondent wrote that they are still struggling to communicate "why gardens are important when not having them is easier for overwhelmed maintenance staff and facilities personnel". The highest response to identifying Edible Campus barriers was "receiving support" at $31.8 \%$. The lowest response was "expanding the Edible Campus" at $15.9 \%$.

Finally, respondents also described a discontent between maintenance, students, and Edible Campus staff. For example, one respondent felt that the campus community was not comfortable stopping by the gardens "to do some weeding, maintenance or harvest as the season progresses". Another respondent discussed how smokers put out their cigarette butts in planting pots calling into question "is garden work part of an education or maintenance work?".

It should be noted that participants had the option to decline any questions or not include a text response. The section of the survey that asked about barriers had a very high response rate.

\section{Benefits of an Edible Campus}

The research participants were asked "What do you feel is the greatest benefit to having an Edible Campus?". Many of the responses mirrored the benefits already described in the literature review. However, the responses provided by the research participants provide a more intimate insight into the everyday benefits of campus food production. Furthermore, in some instances the 
benefits described by the research participants are specific to the associated post-secondary institution.

Sustainable food education and rallying interest in local food was a common theme among respondents. This theme is reflected within one East Coast participant's response:

Modelling sustainable local food... connecting with the burgeoning local food movement and many people's desire to connect with local healthy food.

The theme is echoed again by a Saskatchewan post-secondary institution:

Raising awareness and educating people on how food systems work. Promoting community interactions. Allowing people to grow their own food.

The experiential learning process of campus food production was emphasized by another research participant who saw the Edible Campus as an "opportunity to step outside of their [students] virtual world and step into a real life ecological experience."

Campus beautification and campus community building was cited by $32 \%$ of respondents. These themes are found within the quote below along with the notion that their Edible Campus creates an opportunity for interdisciplinary communication: 
The Campus is alive during the summer. It creates habitats for fauna. People learn more than harvesting, ecosystemic approach, indigenous pollinators, etc. People from different Departments meet and we even had a marriage last year from two gardeners that met on our garden :) Students talk with staff, which is pretty rare. The Campus is becoming something else than a working or studying place.

An East Coast university offered a grander perspective to the benefits of an Edible Campus:

The campus garden specifically allows us to leave behind our various roles and to simply engage at a very basic level with one another (students, faculty, staff, community members). Much decision making and interaction in our society, and on campuses, is based on hierarchies and divisions. I believe that solutions to our social and environmental problems will require this kind of horizontal engagement. I have focused on using the garden as a way to promote more collective and communicative processes of engagement. Our events have allowed us to make the connections between digging in the dirt and changing the world. How we relate to nature on a daily basis may be one of the most critical political questions of our time (Emphasis mine). 
The East Coast respondent highlighted the place Edible Campuses hold within a framework to address global ecological issues.

\section{Future of Edible Campuses}

Research participants were asked: "How do you envision the future of Edible Campuses?" The question was created with the purpose of understanding if there are collective goals among Canadian Edible Campuses. This information is critical as it can be a launching point for future collaborations between Edible Campus teams.

Increasing funding and expansion were widely cited as future goals for respondent's respective Edible Campuses. For example, some participants described a desire to expand onto rooftops or noted future plans for a building already underway. Others described new produce they would like to cultivate.

Creating community collaborations, research and educational opportunities were also reoccurring themes. However, many respondents described the future of Edible Campuses as the new norm, or as one participate put it, "everywhere, every school, all institutional lands... involve all, feed to live". Another participant wrote:

Edible Campuses should really just be part of an overall approach to building healthier, more sustainable and more communicative communities. My own view is that while we are doing this work, we 
need to also be engaging in education and activism to change current structures, policies and attitudes that are destructive to nature and other species. 


\section{Chapter Five}

\section{Findings}

It is the finding of this research that Edible Campuses often exceed beyond 'greening the school' by demonstrating sustainability through the physical structure, teaching practice, research, and relationships with people and nature. Campus food production is largely recognized, by those who participate in Edible Campuses, as a viable and effective mechanism for linking education, ecological action, and food production.

\section{Section I: Edible Campus Overview}

\section{Sustainability}

Considering, ecological action is often presented as one of the primary rationales for campusbased food production, this research sought to identify potential benefits of Edible Campuses as contributors to campus sustainability. This included an exploration of how Edible Campuses are contributing to alternative food systems, sustainably. As discussed in the literature review (Ecological Issues) industrial large monocultures and mono-cropping are damaging to the natural balance of ecosystems. Of the participants who responded to the question: "are plants chosen with benefits to other species in mind?" 95\% indicated yes. Furthermore, no Edible Campuses participating in this research used pesticides and/or genetically modified organism (GMO) seeds. While industrial monocultures are often criticized for using nonrenewable synthetic materials 
and water waste; all Edible Campuses that participated in this research use compost and many recycled water, reducing water pollution and waste.

\section{Size to Income Earning Potential}

This research asked if the size of the Edible Campus directly impacts its earning potential. While expanding the Edible Campus was only considered an obstacle by $15 \%$ of participants, the $15 \%$ of participants were located in urban environments. Thus, if size impacts earning potential, urban Edible Campuses could face greater financial instability compared to their rural counterparts.

While green walls and other smaller unique growing options carry their own costs, typically larger scale food production is costlier to create and maintain. With that said, when examining the relationship between size and income there is little correlation aside from the two extreme sides of the size spectrum. Edible Campuses sized between 0-300 square acres had an average income of $\$ 0$ - $\$ 500$ dollars. Edible Campuses at the largest size measured by the survey $(3,000+$ square acres) had an average income of $\$ 20,000+$ dollars. With one exception, the $3,000+$ square acre Edible Campuses with an income below $\$ 20,000$ indicated an average income of the second and third highest income options $(\$ 10,000$ - \$20,000 and \$5,000-\$10,000). The middle-sized options which ranged from 500 square acres to 15,000 square acres had a range of income levels with no discernible pattern.

Seemingly, a relatively small Edible Campus 301-500 square acres has a similar earning potential to a 1001-1500 square acre Edible Campus. However, it should be noted that these findings only provide a surface deep cost analysis of Edible Campuses. For example, we are 
unable to know the initial startup and maintenance costs in comparison to Edible Campus income. Thus a small garden may have a lower income but a higher net value after maintenance costs.

\section{Spaces Edible Campuses Occupy}

The findings of the survey also shed light on the diversity of Canadian Edible Campuses. Namely, the unique forms food production takes on campuses and the transformation a campus undergoes to become an Edible Campus. Research participants described transforming unused spaces like old soccer fields into spaces for food production, learning and research. The data demonstrates that Edible Campuses have the capacity to elicit positive transformations to both the campus and teaching practices as well as serving as platforms for new and exciting research. Furthermore, Figure 4.0: Types of Edible Campuses provides an overview of the food production projects that make up the Edible Campuses at participating universities. The survey question which provided the data for Figure 4.0 had a $100 \%$ response rate thus Figure 4.0 represents a comprehensive depiction of current Canadian Edible Campus practices.

Interestingly, campus beautification was cited among $36 \%$ of respondents as one of the key benefits of an Edible Campus. Within the scholarship explored in the literature review that examined the benefits of community and campus gardening, beautification was not a priority. When campus beautification is addressed within scholarly discussions it is primarily presented through the scope of ecological reform. For example, highlighting how garden plots are often created on unused or barren land. 


\section{Section II: Identifying Barriers}

\section{Funding and Commitment from Post-Secondary Institution}

One of the critical findings of this research was that when asked about barriers and given the option of 'other' the majority of participants communicated a lack of commitment from the university/college. Furthermore, many participants felt that communicating the importance of the Edible Campus is still a barrier they have to overcome. This finding mirrors the account of implementing sustainable practices at Unity College described in the literature review. Given recognition that sustainable practices have had at United Nation summits and among leaders in higher education it was unexpected that communicating the importance of campus food projects was still a barrier for $22 \%$ of participants.

This research also aimed to consider how financially stable Edible Campuses are. Based on Figure 3.0: Funding Sources we can see that Edible Campuses are funded almost equally by Edible Campus generated revenue (23\%) and funding from the affiliated post-secondary institution (25\%). Only two Edible Campuses marked Edible Campus generated revenue as the sole funding source. As noted in the opposition to Edible Campuses section, critics of alternative

food systems point out the financial instability of these ventures. Quoted in Chapter Four, Section II: Qualitative Responses, one research participate describes how current financial supports are not conducive to innovative alternative food systems, in particular Edible Campuses. The research participant described the dilemma of choosing between developing the Edible Campus into a community garden or receiving financial government support. 
As illustrated by the above statistics, Edible Campuses are largely not self-sustaining I do not believe that translates to Edible Campuses being financially unstable. The mean number of funding sources was 3.8. In the event that one funding source diminishes or revokes support the Edible Campus can rely on additional sources - though it could be argued that this statement would be tempered by the loss of a major funding source. However, I stipulate that the two primary funding sources, Edible Campus generated revenue and funding from the post-secondary institution, would likely be the two most stable funding sources of the available options. However, Edible Campuses, like any alternative food system, are more vulnerable to wavering support than competing large scale industrial food systems. Nevertheless, as Edible Campuses become more fully integrated into post-secondary teaching and research they may be viewed as an essential component of higher education leading to greater financial stability.

For instance, within Section II of Chapter Four (Qualitative Responses) one participant described how their administration is only interested in funding teaching needs. The administration does not perceive the Edible Campus as a platform for education, thus disconnecting it from the finances allocated for education. As detailed below (Future of Edible Campuses) participants articulate how they envision Edible Campuses as the new norm which conceivably could lead to great financial support from government agencies and post-secondary institutions.

\section{Section III: Future of Edible Campuses}

The scholars explored in the literature review who advocate in their texts for educational reform oriented towards sustainability largely focus on reforming learning processes. Namely, updating curriculum to reflect sustainability education, challenging what a classroom space looks like, and 
encouraging creative entrepreneurial thinking amongst students. Reference to campus sustainability projects as platforms for academic research is scarce. Similarly, the capacity Edible Campuses have for being the subject of or platform to academic research is rarely presented within promotional material. However, $61.9 \%$ of individuals active in Edible Campuses state that their Edible Campus is used for research. Of the $38.1 \%$ of Edible Campuses not being used for research, 50\% saw research as a future goal. Individuals working on Edible Campuses view research as an important aspect and goal for Edible Campuses. This position should be featured within future rationales for Edible Campuses. This apparent gap between published research and the experience of Edible Campus participants may also be a reflection of the emerging field of Edible Campus research.

The premise of the ECD was to encourage shared learning processes. This need was supported by the finding that only $22.2 \%$ of participants have used a design from another Edible Campus or urban agriculture project. The potential for future collaborations between Edible Campuses is exciting when considering that $50 \%$ of participants indicated that their Edible Campus led to the creation of an environmental sustainable design project. 


\section{Chapter Six}

\section{Discussion \& Conclusion}

\section{Edible Education}

Localized food systems are an ideal pathway to promote the resolution of environmental, social and economic issues in the food system. As discussed within the literature review, education is often named as a primary building block in shifting towards an alternative or localized food system. Alice Waters (2009) created a list of five edible education principles. The first on the list is "food is an academic subject". Waters wrote "ecology and gastronomy bring alive every subject from reading and writing to science and art" (2009, p.18). Waters coined the term edible education to describe a new wave of sustainable food education. Edible education places a

sense-oriented experience at the centre of scholastic life. We do this through placing food and food concerns at the centre of - not only the school lunch program - but at the centre of the curriculum of the whole school. (Waters, 2009 p.18)

Waters writes this in reference to the public school system but her vision could translate to higher education. Waters describes what edible education looks like in practice:

It means math becomes a practical, hands-on class taught in the environment of the farm and garden. A language class is enhanced by the translation of recipes or stories from other 
cultures. A biology class is illuminated by the activity in a compost heap or by studying and observing living animals and their habits. All classes are embedded in real, evolving, living environments. Things like biodiversity and interconnectedness and empathy are experienced instead of just talked about.

(Waters, 2009, p.18)

Waters' vision for edible education is not just “'greening schools' or an environmental awareness class, or the label on a piece of fruit, it's a larger and more radical approach to teaching our kids how to live and trust their deeper selves, how to embrace Slow Food culture" (Waters, 2009, p. 20). Waters' description of edible education mirrors the living school/living campus concept (O’Brien \& Howard, 2016; O’Brien \& Adam, 2016) that also takes a holistic, experiential approach to incorporating sustainability into all aspects of the college/university or school. Edible Campuses can be valuable contributors to edible education and contribute to living campuses, thus elevating their recognition with respect to campus sustainability in general and social sustainability in particular.

\section{Benefits and Downfalls of Small Localized Projects}

Edible Campuses involve a re-focusing on smaller localized scale which, authors like Ehrenfeld (2008) argues, have the possibility of constructing more engaging, open and sustainable communities based in the present context of lived reality. The campus-sized scale allows for an active, practical as well as future-oriented vision for sustainability. The notion of an dynamic, productive, creative sustainability is also reflected in Ehrenfeld's sustainability ethos: 
Sustainability is only a powerful vision humans can use individually and collectively, to design the world in which they live and act so that the possibility of flourishing is never closed off (Ehrenfeld 2008, p. $54)$.

Edible Campuses are undoubtedly a form of sustainability that is creative and proactive. Campus-scale food production moves beyond municipal or even national participatory planning because Edible Campuses are spaces that are conceived, designed and implemented on a grassroots level. They have the potential to produce new, open and creative uses of space that reflect local community interests thus engaging actors in their neighbourhood and city in new and unforeseen ways.

While food production projects must always consider available materials within frameworks of economy, demography, geography and democracy, there are still opportunities for Edible Campuses to share mutually beneficial learning processes. Edible Campuses have the potential to teach current and future leaders about sustainable food production. However, Edible Campuses rely on support from the associated college/university which $22 \%$ of participants of this study feel is not adequately met at their institution.

\section{Future Research}

This research asked participants to identify barriers that deter developments of Edible Campuses. Financial support, lack of commitment to sustainable practices along with a perceived lack of 
understanding regarding the benefits of an Edible Campus were most cited. Within the qualitative responses participants linked the lack of financial support to the limited commitment from the university/college as well as the perceived lack of understanding regarding the benefits of an Edible Campus. In essence, administrators are less likely to allocate funds to projects that do not have quantifiable benefits. These findings support future empirical research into Edible Campuses as ideological barriers were more frequently identified as opposed to physical barriers such as expanding the Edible Campus into other areas. Despite these ideological barriers, postsecondary institutions offer considerable latitude with student autonomy and the academic freedom of instructors to foster change through research, teaching and community service. Further research could investigate the levers for mobilizing and sustaining change towards sustainable campus food production.

Livestock was excluded from this research's definition of Edible Campuses as it would shift focus away from small urban campuses towards larger rural campuses. Despite size or location, a post-secondary institution has the capacity to cultivate fruits, vegetables and herbs.

Considering the growing interest in nature connection and well-being (Zelenski \& Nisbet, 2014), future research could examine how Edible Campuses interconnect with nature and deepen our understanding of the natural world as well as human well-being. This has the potential for fostering more explicit integration of campus well-being initiatives with sustainability. Furthermore, Edible Forests are a unique subset of Edible Campuses that merit further exploration. It is my understanding that Edible Forests are slowly transgressing the theoretical into the practical on post-secondary campuses. 
The literature review outlines the current evaluation frameworks that could be adapted to be applied to Edible Campuses. Questions regarding evaluation frameworks went beyond the scope of the survey and would have made a voluntary survey rather lengthy. Furthermore, research into an Edible Campus evaluation framework would need to be the primary focus of a research project to explore this area in greater depth. I believe it is a topic that merits further investigation. An evaluation framework that intertwines sustainable food production, education and well-being is a desperately needed in higher education. The Canadian ECD could serve as a resource for implementing this research by providing case studies, network for collaborations and an overview of current practices.

\section{Summary}

Returning to Micheal Pollan's writing that began this thesis, no acts of growing food are small or meaningless. While, "Measured against the Problem We Face, planting a garden sounds pretty benign, I know, but in fact it's one of the most powerful things an individual can do — to reduce your carbon footprint, sure, but more important, to reduce your sense of dependence and dividedness: to change the cheap-energy mind.” (Pollan, 2008a, para 20). And in the words of one of the research participants "How we relate to nature on a daily basis may be one of the most critical political questions of our time". 


\section{Appendices}

Appendix 1: Recruitment Email

\section{[To Whom it May Concern],}

My thesis examines the best practices of Canadian campus-based food production projects. As a member of [Name of Edible Campus], I would like to invite you to participate in my thesis research.

Participation would mean completing a short survey which will ask questions regarding the inception, maintenance, and inspirations for the project. Below is a sample of the survey questions:

- How is the harvest utilized?

- How was the location utilized prior to the garden?

- How does the garden benefit the surrounding community?

If you choose to participate in the study you will have the option to request a pseudonym, decline to answer any questions in the survey and withdraw your data from the study entirely prior to February 28th, 2017. Additionally, the thesis will include a disclaimer indicating that the results of the survey reflect the personal opinions of the participants, not the affiliated campus.

Participants will receive a copy of the research upon its completion.

I hope you consider participating in this research. Please contact me with any questions or if I should redirect this inquiry to another individual at your campus.

Sincerely,

Sean O’Brien Murray 


\title{
RYERSONUNIVERSITY
}

Appendix 2: Consent Agreement Template

\author{
Ryerson University \\ Survey Consent Agreement \\ "How to Grow an Edible Campus"
}

You are being invited to participate in a research study, How to Grow an Edible Campus. Please read this consent form so that you understand what your participation will involve. Before you consent to participate, please ask any questions to be sure you understand what your participation will involve.

\section{TITLE: How to Grow an Edible Campus}

\section{INVESTIGATORS:}

This research study is being conducted by Sean O'Brien Murray, Graduate student, MA Program in Communication and Culture at Ryerson University. The research is supervised by Dr. Stéphanie Walsh Mathews from the Department of Languages, Literatures, and Cultures, Faculty of Arts, at Ryerson University.

If you have any questions or concerns about the research, please feel free to contact Sean Murray at sean1.murray@ryerson.ca or Dr. Walsh Matthews at swalsh@arts.ryerson.ca

\section{PURPOSE OF THE STUDY:}

This research is part of a thesis which is a requirement of the Master of Arts Communication and Culture program at Ryerson University. You have been invited to participant in the study because of your involvement in a campus-based food production project or 'Edible Campus'. This study survey's Edible Campus projects across Canada. The purpose of the study is to understand the best practices and future applications of the Edible Campuses.

\section{WHAT YOU WILL BE ASKED TO DO:}

You will receive a list of survey questions through email (sample question provided below). If you have any questions or hesitations about the survey, please contact the primary researcher. Return the completed survey to the primary researcher through email.

The survey will not require demographic information. You can decline to answer any questions you are not comfortable with. Declining to answer any or all questions will not affect your future relationship with Ryerson University the defence committee or the primary researcher.

\section{Sample Survey Questions:}


2.4 Has the Edible Campus expanded since its creation? YES/NO

(A) If YES please describe:

3.1 Who maintains the Edible Campus? E.g volunteers, students, community members.

(A) IF YES please specify the approximate amount of people for each category.

5.3 How is the Edible Campus harvest utilized?

6.2 How was the location utilized prior to the Edible Campus?

7.3 How does your Edible Campus benefit the surrounding community?

POTENTIAL BENEFITS:

A potential benefit to participating in this study is furthering research which contributes to environmental sustainability and food security scholarship. You may request a copy of the findings upon the completion of the research. Please note that I cannot guarantee that you will receive any benefits from participating in this study.

\section{WHAT ARE THE POTENTIAL RISKS TO YOU AS A PARTICIPANT:}

Risks to you participating in this research is very low. A potential risk is feeling uncomfortable with the survey questions. If you feel uncomfortable you may decline to answer any or all of the questions. You may also withdraw your data from the study entirely prior to February 28th, 2017. Following February 28th, 2017 the data collected will be used for analysis.

\section{CONFIDENTIALITY:}

1. All data, including hard copy material will be stored on a secure hard drive and shared only the thesis supervisor.

2. If you do not request a pseudonym the identity and post-secondary affiliations will be shared within field notes, correspondence and within the final research. If you would like to request a pseudonym please check and sign asking for a pseudonym at the bottom of this consent form. If you request a pseudonym your identity will be safeguarded and only known to the primary researcher and supervisor. Only with your written consent can additional individuals be privy to your identity.

3. The information linking the pseudonym to the research participant will be stored on a separate password protected hard drive.

4. The data collected will be stored for the full length of the research and destroyed upon completion of the research. The expected completion of the research is April, 2017.

5. You may also withdraw your data from the study entirely prior to to February 28th, 2017.

Following to February 28th, 2017 all data collected can be used for analysis.

\section{INCENTIVES FOR PARTICIPATION:}

You will not be paid to participate in this study.

\section{VOLUNTARY PARTICIPATION AND WITHDRAWAL:}

Your participation is entirely voluntary. You may choose not to answer any or all questions related to this research. You may also withdraw your data from the study entirely prior to to 
February 28th, 2017. Following to February 28th, 2017 the data can be included for analysis. However, at any point, you can request a pseudonym (please see the confidential section for more detail). Full withdrawal or answering a select amount of questions will not influence any future relations with the researcher, defence committee, thesis supervisor or Ryerson university.

\section{QUESTIONS ABOUT THE STUDY:}

If you have any questions about the research now, please ask. If you have questions later about the research, you may contact.

Primary Researcher:

Sean Murray

sean1.murray@ryerson.ca

Thesis Supervisor:

Stéphanie Walsh Mathews

Telephone: 416-979-5000 ex. 7357

Email:swalsh@arts.ryerson.ca

This study has been reviewed by the Ryerson University Research Ethics Board. If you have questions regarding your rights as a participant in this study please contact:

Research Ethics Board

c/o Office of the Vice President, Research and Innovation

Ryerson University

350 Victoria Street

Toronto, ON M5B 2K3

416-979-5042

rebchair@ryerson.ca 


\section{How to Grow an Edible Campus}

\section{CONFIRMATION OF AGREEMENT:}

Your signature below indicates that you have read the information in this agreement and have had a chance to ask any questions you have about the study. Your signature also indicates that you agree to participate in the study and have been told that you can change your mind and withdraw your consent to participate at any time. You have been given a copy of this agreement.

You have been told that by signing this consent agreement you are not giving up any of your legal rights.

Name of Participant (please print)

Signature of Participant

Date

Please check if you would like a pseudonym. You can change your choice at any point during the research if you contact sean1.murray@ryerson.ca. 


\section{RYERSON UNIVERSITY}

Sean O'Brien Murray

MA Communication and Culture, Ryerson University

\section{Participant Rights:}

\section{HOW TO GROW AN EDIBLE CAMPUS}

You may decline to answer any questions or withdraw from the study entirely. Doing so will not affect future relations with the primary researcher, Sean Murray, or Ryerson University. After February 28th, 2017 data collected cannot be withdrawn and will be analyzed. At any point during the research the participant may request a pseudonym. For additional details please refer to the consent agreement or email the primary researcher.

\section{Survey Instructions:}

1. Defining Edible Campus: Edible Campus is a term used to describe campus-based food production and may include multiple edible projects on one campus.

2. The goal of this research is to examine the overarching concept of Edible Campuses. If your post-secondary institution has multiple edible projects please consider all projects within your responses. If you wish to reference a single project, please indicate clearly that you are doing so.

3. Please check the BLUE box if the question is not applicable or you are declining to answer the question.

4. Please check the GREEN box at the end of the survey if you would like your email to be used as the point of contact with the Canadian Edible Campus Database.

Please contact primary researcher, Sean O'Brien Murray, with any questions or concerns regarding this survey: sean1.murray@ryerson.ca 


\subsection{PARTICIPANT INFORMATION:}

1.1 Position at post-secondary institution:

\begin{tabular}{|l|l|}
\hline &
\end{tabular}

1.2 When did you begin working on the Edible Campus project? (DD/MM/YYYY)

1

1.3 Please briefly describe your role within the Edible Campus:

\subsection{EDIBLE CAMPUS DESCRIPTION:}

2.1 What is your Edible Campus called? Please include multiple titles if applicable:

2.2 How was the name of you Edible Campus chosen? Check all factors that influenced the decision:

Location of the Edible Campus

Funding source

Post-secondary institution

Other

If OTHER please describe:

2.3 When was the Edible Campus first proposed? (DD/MM/YYYY)

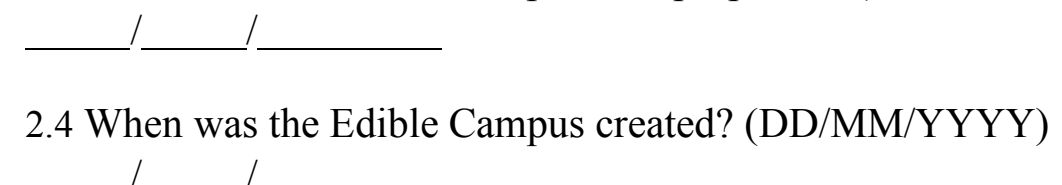


2.5 What is the current approximate size of the Edible Campus?

$\square-300$ Square metres
$\square \quad 301-500$ Square metres
$\square 01-800$ Square metres
$\square \quad 801-1000$ Square metres
$\square \quad 1001-1500$ Square metres
$\square 01-3000$ Square metres
$\square 3001 \mathrm{~m} \mathrm{Sq}+$

2.6 Please identify the space[s] the Edible Campus occupies. Please check all that apply:

$\square$ Rooftop
$\square$ Classrooms
$\square$ Campus green space
$\square$ Offices
$\square$ Other

If OTHER please describe:

2.7 Has the Edible Campus expanded in size since its creation?

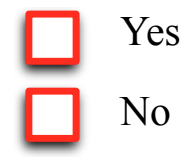

2.8 Are there plans for your Edible Campus to expand in size?

$\square$ Yes
$\square$ No


2.9 What departments at your post-secondary institution have collaborated on the Edible Campus?

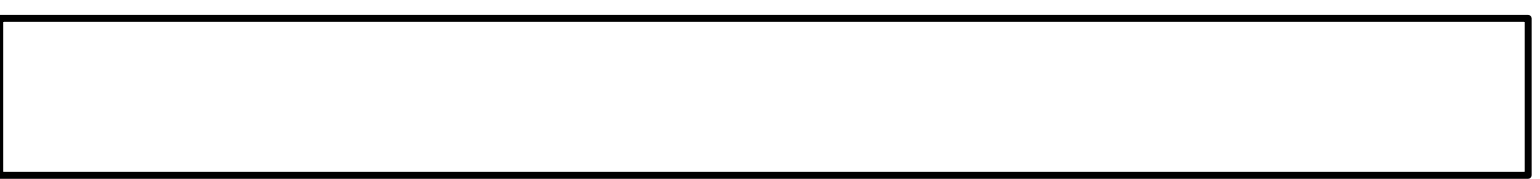

\subsection{EDIBLE CAMPUS MAINTENANCE:}

3.1 Who governs the Edible Campus? Please check all that apply:

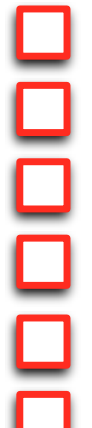

Volunteers

Students

Community members

Faculty/staff

Funding partners

Other

If OTHER please describe:

3.2 Who maintains the Edible Campus? Please check all that apply:

Volunteers

Students

Community members

Faculty/staff

Funding partners

Other

If OTHER please describe: 
3.3 Who determines what will be planted in the Edible Campus? Please check all that apply:
Volunteers
Students
Community members
Faculty/staff
Funding partners
Other

If OTHER please describe:

3.4 Has your Edible Campus team increased, decreased or remained constant since its inception?

\section{Increased \\ Decreased \\ Remained constant}

3.5 Are the people who care for the Edible Campus incentivized or compensated?

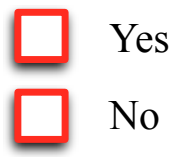

IF YES: Please describe the nature of the incentive: 
3.6 What strategies does your Edible Campus employ to ensure continued interest from those who support the Edible Campus? Please check all that apply:

$\square$ Community engagement
Staff/faculty engagement
Brochures
$\square$ Farmers markets
$\square$ Integrated into coursework
$\square$ Advertisements
$\square$ Other

If OTHER please describe:

\subsection{FUNDING:}

4.1 What was the estimated income of your Edible Campus last year, including income from funding sources and revenue?

$$
\begin{array}{ll}
\square & 0 \$-500 \$ \\
& 501 \$-1,000 \$ \\
\square & 1,001 \$-2,000 \$ \\
& 2,001 \$-5,000 \$ \\
\square, 001 \$-10,000 \$ & 10,001 \$-20,000 \$ \\
& 20,001 \$+
\end{array}
$$


4.2 How is the Edible Campus funded? Please check all that apply for both past and current funding sources:

$\square$ Sponsors
$\square$ Community support
$\square$ Government support
$\square$ The affiliated post-secondary institution
$\square \quad$ Edible Campus generated revenue
Other

If OTHER please identify:

4.3 What are future funding goals?

$\begin{array}{ll}\square & 0 \$-500 \$ \\ & 501 \$-1,000 \$ \\ \square & 1,001 \$-2,000 \$ \\ & 2,001 \$-5,000 \$ \\ \square, 001 \$-10,000 \$ \\ \square \\ 10,001 \$-20,000 \$ \\ 20,001 \$+\end{array}$




\subsection{USES FOR THE EDIBLE CAMPUS:}

5.1 Is your Edible Campus used as a platform for education?

$$
\begin{aligned}
& \text { Yes } \\
& \text { No }
\end{aligned}
$$

IF YES: Please briefly explain how:

If NO: Is education a future goal for your Edible Campus?

5.2 Is the Edible Campus used for research?

$$
\text { Yes }
$$

No

IF YES: Please briefly explain how:

IF NO: Is research a future goal for your Edible Campus? 
5.3 How is the Edible Campus harvest utilized? Please check all that apply:

As a source of revenue for the Edible Campus

As a means of food security

As an incentive for the Edible Campus team

Other

If OTHER please identify:

5.4 Has your Edible Campus used designs from another Edible Campus or urban agriculture project?

Yes

No

IF YES: please describe the design, and the origin of the design:

5.5 Is the Edible Campus used during the off seasons?

Yes

No

Comment optional: 


\subsection{ENVIRONMENTAL SUSTAINABILITY:}

6.1 How was the Edible Campus location utilized prior to the food production? Please check all that apply:

$\square$ Unused concrete area (e.g. rooftop)
$\square$ Used concrete area (e.g. parking lot)
$\square \quad$ Floral garden
$\square$ Green space (e.g. lawn)
$\square$ Other

If OTHER please identify:

6.2 How is the water sourced for the Edible Campus? Please check all that apply:

$\square$ Rain water collection
Recycling garden runoff
$\square$ Nearby body of water
$\square$ Municipal water supply
$\square$ Well water
$\square$ Other

If OTHER please identify: 
6.3 Has your Edible Campus led to the creation of any environmentally sustainable design projects? E.g. waste management systems.

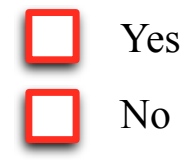

IF YES: please describe and note if another post-secondary institution with an Edible Campus used your design:

6.4 Are any Edible Campus plants chosen with benefits to other species in mind?

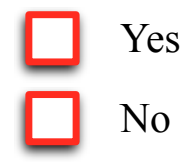

6.5 Does your Edible Campus use compost?

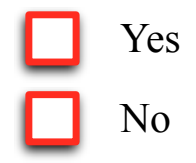

6.6 Does your Edible Campus grow genetically modified organisms (GMO's)?

$\square$ Yes
$\square \quad$ No




\subsection{COMMUNITY AND COLLABORATION:}

7.1 Is the Edible Campus accessible by all? For example, can the surrounding community access it?

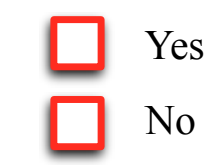

Comment optional:

7.2 Has your Edible Campus partnered with community organizations?

Yes

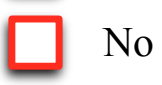

IF YES: please describe the benefits of the partnership:

7.3 Does your Edible Campus team coordinate with similar projects?

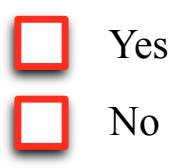

IF YES: Please name the projects and describe how the collaboration influenced the development or maintenance of your Edible Campus: 
7.4 If applicable, please discuss Edible Campus or urban agriculture case studies that have inspired you:

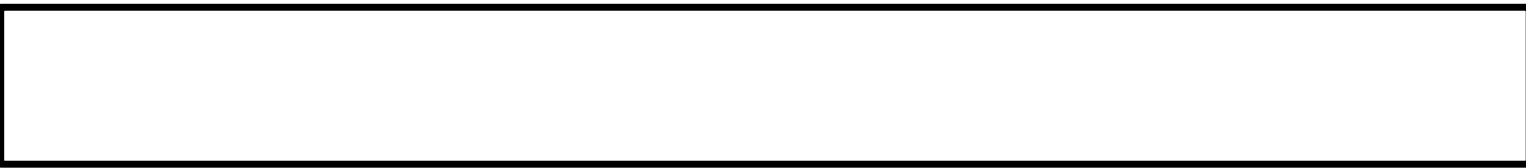

\subsection{PROBLEM SOLVING:}

8.1 What are obstacles your Edible Campus had to overcome? Please check all that apply:

Receiving funding

Continued support

Expanding the Edible Campus

Other

If OTHER please identify:

8.2 What are the barriers for expanding the Edible Campus into other facets of your postsecondary institution? Please mention what these facets are:

\subsection{FUTURE POSSIBLITIES:}

9.1 How do you envision the future of Edible Campuses? 
9.2 What administrative or policy barriers do you believe exist which deter developments of Edible Campuses?

9.3 What are the opportunities for expanding the Edible Campus into other facets of your post-secondary institution?

\subsection{CONCLUSION}

10.1 What do you feel is the greatest benefit to having an Edible Campus?

10.2 The Edible Campus database is growing in part from referrals, please name the Edible

Campus projects that you know of:

10.3 Please add any additional comments here.

Thank you for participating in this survey!

Please check the GREEN box if you would like your email to be used as the point of contact for your Edible Campus project within the Canadian Edible Campus database. The database will be shared with individuals who have participated in this research or are interested in Edible Campus research. 


\section{References}

Aber, J., Kelly, T., \& Mallory, B. (2009). The sustainable learning community (1st ed.). Durham, N.H.: University of New Hampshire Press.

About-ULSF. (2017). Ulsf.org. Retrieved 31 May 2017, from http://ulsf.org/about/

Allen, P. (2010). Realizing justice in local food systems. Cambridge Journal of Regions, Economy and Society, 3(2), 295-308. http://dx.doi.org/10.1093/cjres/rsq015

American College and University Presidents Agreement. (2009). A call for climate leadership progress and opportunities in addressing the defining challenge of our time. Retrieved from http://hub-media.aashe.org/uploads/A_Call_for_Climate_Leadership.pdf

Armstrong, D. (2000). A survey of community gardens in upstate New York: Implications for health promotion and community development. Health \& Place, 6(4), 319-327. http://dx.doi.org/10.1016/s1353-8292(00)00013-7

Association for the Advancement of Sustainability in Higher Education [AASHE]. (2017). Retrieved from http://www.aashe.org

Organic Farming | ATTRA | A national sustainable agriculture assistance program. (2017). Attra.ncat.org. Retrieved 3 August 2017, from https://attra.ncat.org/

Barlett, P. (2011). Campus sustainable food projects: Critique and engagement. American Anthropologist, 113(1), 101-115. http://dx.doi.org/10.1111/j.1548-1433.2010.01309.x 
Barlett, P., \& Chase, G. (2013). Sustainability in higher education (p. 244). Cambridge, Mass.: MIT Press.

Beringer, A. (2006). Campus sustainability audit research in Atlantic Canada: pioneering the campus sustainability assessment framework. International Journal of Sustainability in Higher Education, 7(4), 437-455. http://dx.doi.org/10.1108/14676370610702235

Bhatt, V., Farah, L., Luka, N., \& Wolfe, J. (2009). Making the edible campus: A model for food-secure urban revitalisation. Open House International, 34(2).

Black, K. (2014). New South Campus garden grows conversation on food security. UniversityofAlberta.ca. Retrieved 14 June 2017, from https://www.ualberta.ca/newsand-events/newsarticles/2014/july/new-south-campus-garden-grows-conversation-onfood-security

Bon Appetit Management Company. (2009). Student gardens and food service. Retrieved from http://civileats.com/wp-content/uploads/2009/09/student_garden_guide_final__food_service.pdf

Bowdoin Dining Services. Bowdoin.edu. Retrieved 15 June 2017, from http://www.bowdoin.edu/dining/

Brinkhurst, M., Rose, P., Maurice, G., \& Ackerman, J. (2011). Achieving campus sustainability: Top-down, bottom-up, or neither?. International Journal of Sustainability in Higher Education, 12(4), 338-354. http://dx.doi.org/10.1108/14676371111168269 
Brock University. (2013). Growing greener campuses at Ontario universities. Retrieved from https://brocku.ca/webfm_send/33152

Canadian Association of College \& University Student Services and Canadian Mental Health Association (CACUSS and CMHA). (2013). Vancouver.

Carpenter, N. (2009). Farm city: The education of an urban farmer (1st ed.). Penguin Books.

Chaparro, MP., Zaghloul, SS., Holck, P., \& Dobbs, J. (2009). Food insecurity prevalence among college students at the University of Hawai'i at Mānoa. Public Health Nutrition, 12(11), 2097. http://dx.doi.org/10.1017/s1368980009990735

Clavin, A. (2011). Realising ecological sustainability in community gardens: A capability approach. Local Environment, 16(10), 945-962. http://dx.doi.org/10.1080/13549839.2011.627320

Cockrall-King, J. (2012). Food and the city (1st ed.). Amherst, N.Y.: Prometheus Books.

Company, B. (2017). Campus Farmers - Bon Appétit Management Co.. Bon Appétit Management Co.. Retrieved 8 June 2017, from http://www.bamco.com/timeline/campus-farmers/

Co-operative Food Empowerment Directive. (2011). CoFed manual for starting student-run food cooperatives. Retrieved from http://cultivatingfoodcoops.net/wp2012/wpcontent/uploads/2012/05/Starting-a-Student-Run-Food-Co-op-COFED.pdf 
Creighton, S. (1998). Greening the ivory tower: Improving the environmental track record of universities, colleges, and other institutions. Massachusetts Institute of Technology. http://dx.doi.org/10.5860/choice.36-1538

Creighton, S. (1999). Greening the ivory tower. Cambridge, Mass.: MIT Press.

D'Abundo, M., \& Carden, A. (2008). "Growing wellness": The possibility of promoting collective wellness through community garden education programs. Community Development, 39(4), 83-94. http://dx.doi.org/10.1080/15575330809489660

Despommier, D. (2011). The vertical farm: Feeding the world in the 21st century (1st ed.). New York: Picador.

Developing a population health promotion model. (2017). Phac-aspc.gc.ca. Retrieved 15 June 2017, from http://www.phac-aspc.gc.ca/ph-sp/php-psp/php3-eng.php

Draper, C., \& Freedman, D. (2010). Review and analysis of the benefits, purposes, and motivations associated with community gardening in the United States. Journal of Community Practice, 18(4), 458-492. http://dx.doi.org/10.1080/10705422.2010.519682

Druker, S., \& Goodall, J. (2015). Altered genes, twisted truth. Clear River Press.

Dupuis, E., Goodman, D., \& Harrison, J. (2006). Just values or just value? Remaking the local in agro-food studies. Research in Rural Sociology and Development, 12, 241-268. http://dx.doi.org/10.1016/s1057-1922(06)12010-7 
Ehrenfeld, J. (2008). Sustainability by design: A subversive strategy for transforming our consumer culture. Yale University Press. http://dx.doi.org/10.1111/j.15309290.2009.00209.x

Fair Trade Colleges and Universities Toolkit (pp. http://fairtradecampaigns.org/wpcontent/uploads/2013/12/FTCU-Toolkit.pdf).

Finlay, J., \& Massey, J. (2012). Eco-campus: Applying the ecocity model to develop green university and college campuses. International Journal of Sustainability in Higher Education, 13(2), 150-165. http://dx.doi.org/10.1108/14676371211211836

Foley, J. (2014). Feeding 9 billion. National Geographic. Retrieved from http://www.nationalgeographic.com/foodfeatures/feeding-9-billion/

Food Actions | UCSB Sustainability. Sustainability.ucsb.edu. Retrieved 15 June 2017, from http://www.sustainability.ucsb.edu/food-actions/

Friedmann, H. (1993). The political economy of food: A global crisis. New Left Review, 197, $29-57$.

FSU Sustainable Campus Initiative. (2011). AASHE STARS Reporting Tool. Retrieved from http://www.sustainablecampus.fsu.edu/sites/g/files/imported/storage/original/application /1a493d794791d78241a2603393a93701.pdf

Fullan, M. (2013). Stratosphere: Integrating technology, pedagogy, and change knowledge (1st ed.). Toronto, Canada: Pearson. 
Fullan, M., \& Langworthy, M. (2014). A rich seam: How new pedagogies find deep learning. London: Pearson.

Ghahramanpouri, A., Lamit, H., \& Sedaghatnia, S. (2013). Urban social sustainability trends in research literature. Asian Social Science, 9(4). http://dx.doi.org/10.5539/ass.v9n4p185

Gibson-Graham, J. (1997). The end of capitalism (as we knew it): A feminist critique of political economy. Capital \& Class, 21(2), 186-188.

http://dx.doi.org/10.1177/030981689706200111

Gliessman, S. (2013). A food crisis spawns an alternative food movement. Agroecology and Sustainable Food Systems, 38(1), 1-2. http://dx.doi.org/10.1080/21683565.2013.840716

Goodman, D., Goodman, M., \& DuPuis, E. (2014). Alternative food networks (1st ed.). London: Routledge, Taylor \& Francis Group.

Gorgolewski, M., Komisar, J., \& Nasr, J. (2011). Carrot city (1st ed.). New York: Monacelli Press.

Government of Ontario. (2017). Green schools resource guide. Retrieved from http://www.edu.gov.on.ca/eng/policyfunding/GreenSchools_Guide.pdf

Hassanein, N. (2008). Locating food democracy: Theoretical and practical ingredients. Journal of Hunger \& Environmental Nutrition, 3(2-3), 286-308. http://dx.doi.org/10.1080/19320240802244215 
Hopkins, C. (2013). Educating for sustainability: An emerging purpose of education. Kappa Delta Pi Record, 49(3), 122-125. http://dx.doi.org/10.1080/00228958.2013.819193

ISCN in Collaboration with GULF of The World Economic Forum. (2017). Educating for sustainability. Retrieved from https://www.international-sustainable-campusnetwork.org/downloads/general/462-educating-for-sustainability/file

Ladner, P. (2011). The urban food revolution (1st ed.). Gabriola Island, BC: New Society Publishers.

Lappé, A. (2010). Diet for a hot planet (1st ed.). New York: Bloomsbury.

Lappé, F. (1985). Diet for a small planet (1st ed.). New York: Ballantine Books.

Lappé, F., \& Collins, J. (2015) World hunger: 10 myths. New York: Grove Press.

Lappé, F., \& Lappé, A. (2005). Hope's edge (1st ed.). New Delhi: Viveka Foundation.

Lau, S., \& Yang, F. (2009). Introducing healing gardens into a compact university campus: Design natural space to create healthy and sustainable campuses. Landscape Research, 34(1), 55-81. http://dx.doi.org/10.1080/01426390801981720

Lawson, L. (2005). City bountiful: A century of community gardening in America. Choice Reviews Online, 43(03), 43-1557-43-1557. http://dx.doi.org/10.5860/choice.43-1557

Lyson, T. (2004). Civic agriculture, reconnecting farm, food and community. Contemporary Sociology, 34(5), 521-522. http://dx.doi.org/10.1177/009430610503400539 
Lyson, T. (2012). Civic agriculture reconnecting farm, food, and community (1st ed.). Lebanon: Tufts University Press.

Lyson, T., \& Hinriches, C. (2007). Remaking the North American food system: Strategies for sustainability (1st ed.). University of Nebraska Press.

Macleans. (2011). The dirt on farming. Retrieved from http://www.macleans.ca/education/uniandcollege/the-dirt-on-farming/

MacKean, G. (2011). Mental health and well-being in postsecondary education settings: A literature and environmental scan to support planning and action in Canada. Retrieved from http://www.cacuss.ca/_Library/documents/Pos6001t_Sec_Final_Report_June6.pdf

Model \& Framework for Action - Healthy Universities. (2017). Healthy Universities. Retrieved 15 June 2017, from http://www.healthyuniversities.ac.uk/healthyuniversities/model-and-framework-for-action/

Montanari, M., Sonnenfeld, A., \& Flandrin, J. (1999). Food: A culinary history from antiquity to the present. Gastronomica: The Journal of Food And Culture.

NASPA: Student Affairs Administrators in Higher Education. (2010). Leadership for a healthy campus: An ecological approach for student success. Retrieved from http://www.naspa.org/membership/mem/pubs/ebooks/HealthyCampus.pdf 
Oatfield, C. (2010). Best practices for starting sustainable food cooperatives in university communities. Retrieved from http://nature.berkeley.edu/classes/es196/projects/2010final/OatfieldC_2010.pdf

O'Brien, C. (2016). Education for sustainable happiness and well-being (1st ed.). New York: Routledge.

O'Brien, C., \& Adam, C. (2016). Sustainable happiness, living campus, and well-being for all. Journal of Innovation, Creativity, And Change.

OBrien, C., \& Howard, P. (2016). The Living School: The emergence of a transformative sustainability education paradigm. Journal of Education for Sustainable Development, 10(1), 115-130. http://dx.doi.org/10.1177/0973408215625549

O’Brien, C., \& Murray, S. (2017). Transforming ourselves and education through food. $7^{\text {th }}$ International Conference on Food Studies, Food Studies Network (Rome, October, 2017).

Our History | Plant Agriculture. (2017). Plant.uoguelph.ca. Retrieved 29 May 2017, from http://www.plant.uoguelph.ca/about-us/our-history

Palassio, C., \& Wilcox, A. (2009). The edible city: Toronto's food from farm to fork (1st ed.). Toronto: Coach House Books.

Pan-Canadian Joint Consortium for School Health. (2017). Positive Mental Health Indicator Toolkit. Retrieved from https://www.edu.uwo.ca/csmh/resources/Pan- 
Canadian\%20Joint\%20Consortium\%20for\%20School\%20Health\%20-

\%20Positive\%20Mental\%20Health\%20Toolkit.pdf

Patterson, P., \& Kline, T. (2008). Report on post-secondary institutions as healthy settings. Victoria, BC: Health and Knowledge Learning Centre.

Pollan, M. (2008a). Why bother. New York Times Magazine. Retrieved from http://www.nytimes.com/2008/04/20/magazine/20wwln-lede-t.html

Pollan, M. (2008b). In defense of food (1st ed.). New York: Penguin Press.

Pollan, M. (2006). The omnivore's dilemma (1st ed.). New York: Penguin Press

Price, J., \& Gottlieb, R. (2002). Environmentalism unbound: Exploring new pathways for change. Environmental History, 7(1), 148. http://dx.doi.org/10.2307/3985474

Real Food Challenge | Uniting students for just and sustainable food. (2017).

Realfoodchallenge.org. Retrieved 8 June 2017, from http://www.realfoodchallenge.org/

Reynolds, R. (2009). On guerrilla gardening: A handbook for gardening without boundaries (1st ed.). London [u.a.]: Bloomsbury.

Ridgeway, N., \& Matthews, J. (2015). Campus gardens: Food production or sense of place?. Canadian Food Studies / La Revue Canadienne Des Études Sur L'alimentation, 2(1), 99. http://dx.doi.org/10.15353/cfs-rcea.v2i1.23 
Sayre, L. (2011). The student farm movement. Sustainability: The Journal of Record, 4(5), 258-259. http://dx.doi.org/10.1089/sus.2011.9655

Sierra Youth Coalition. (2017). Community supported agriculture assessment. Retrieved from http://140.230.24.4:8080/xmlui/bitstream/handle/10587/153/SSGsustainability2007.pdf? sequence $=1$

Sierra Youth Coalition. On-Campus food systems production, distribution \& best practices. Retrieved from http://www.farmtocafeteriacanada.ca/wp-content/uploads/2014/11/PGIOn-Campus-Food-Systems-copy.pdf

STARS Overview | About $\mid$ AASHE STARS. (2017). Stars.aashe.org. Retrieved 8 June 2017, from https://stars.aashe.org/pages/about/stars-overview.htm

Talloires Declaration - ULSF. (2017). Ulsf.org. Retrieved 15 June 2017, from http://ulsf.org/talloires-declaration/

The campus food revolution | University Affairs. (2017). University Affairs. Retrieved 29 May 2017, from http://www.universityaffairs.ca/features/feature-article/the-campusfood-revolution/

The garden guide. (2010). Retrieved from http://www.farmtocafeteriacanada.ca/wpcontent/uploads/2014/11/RFC-Garden-Guide-Revised-2010.pdf 
The Presidents' Climate Leadership Commitments. (2017). Secondnature.org. Retrieved 31 May 2017, from http://secondnature.org/what-we-do/climate-leadership/'

Thomashow, M. (2014). The nine elements of a sustainable campus (1st ed.). Cambridge, Massachusetts: The MIT Press

United Nations. (1993) Agenda 21: Earth Summit - The United Nations programme of action from Rio. https://unp.un.org/details.aspx?entry=E93020\&title=Agenda+21:+Earth+Summit++ The + United + Nations + Programme + of + Action + from+Rio.United Nations. (2015). COP21 Climate Change Agreement. Paris.

UNESCO. (2005). Guidelines and recommendations for reorienting teacher education to address sustainability. Education for sustainable development in action. Technical paper No. 2. http://unesdoc.unesco.org/images/0014/001433/143370E.pdf.

University Leaders for a Sustainable Future. (2001). Retrieved from http://www.ulsf.org/programs_talloires.html

University of Manitoba - Faculty of Agricultural and Food Sciences - Dept of Animal Science - Glenlea Research Station. (2017). Umanitoba.ca. Retrieved 29 May 2017, from http://umanitoba.ca/faculties/afs/dept/animal_science/facilities/Glenlea\%20Research\%2 0Station\%20Unit.html

UWO-1st Fair Trade campus in US - Sustainability. Uwosh.edu. Retrieved 14 June 2017, from http://www.uwosh.edu/sustainability/fair-trade 
Valen, G. (1992). Hendrix college local food project. New Directions For Higher Education, 1992(77), 77-87. http://dx.doi.org/10.1002/he.36919927710

Van Den Berg, A., \& Custers, M. (2010). Gardening promotes neuroendocrine and affective restoration from stress. Journal Of Health Psychology, 16(1), 3-11. http://dx.doi.org/10.1177/1359105310365577

Vickery, H. (2017). Educating for Sustainability: ISCN and GULF Universities Share Best Practice Report at the World Economic Forum - International Sustainable Campus Network. International-sustainable-campus-network.org. Retrieved 31 May 2017, from https://www.international-sustainable-campus-network.org/news/472-educating-forsustainability-iscn-and-gulf-universities-share-best-practice-report-at-the-worldeconomic-forum

Waters, A. (2009). Edible schoolyard (1st ed.). San Francisco, Calif.: Chronicle.

Watson, J. (2002). Commentary. Current Anthropology, 43(4), 624.

Williams, J., \& Forbes, W. (2012). Toward a more livable world. Nacogdoches, Tex.: Stephen F. Austin State University Press.

Woodcraft, S. (2012). Social sustainability and new communities: Moving from concept to practice in the UK. Procedia - Social And Behavioral Sciences, 68, 29-42. http://dx.doi.org/10.1016/j.sbspro.2012.12.204Wright, W., \& Middendorf, G. (2008). The fight over food (1st ed., pp. 45-67). University Park, Pa.: Pennsylvania State University Press. 
Woodcraft, S., Hackett, T., \& Caistor-Arendar, L. (2011). Design for social sustainability: A framework for creating thriving new communities. Futurecommunities.net. Retrieved from http://www.futurecommunities.net/files/images/Design_for_Social_Sustainability_0.pdf

Zelenski, J. M., \& Nisbet, E. K. (2014). Happiness and feeling connected: The distinct role of nature relatedness. Environment and Behavior, 46(1), 3-23. 